Arboriculture \& Urban Forestry 2014. 40(4): 193-217

\title{
The Management of Tree Root Systems in Urban and Suburban Settings: A Review of Soil Influence on Root Growth
}

\author{
Gary W. Watson, Angela M. Hewitt, Melissa Custic, and Marvin Lo
}

\begin{abstract}
The physical, chemical, and biological constraints of urban soils often pose limitations for the growth of tree roots. An understanding of the interrelationships of soil properties is important for proper management. As a result of the interdependence of soil properties, the status of one soil factor can have an effect on all others. Preventing soil damage is most effective and preferred. Cultural practices, such as cultivation and mulching, can be effective in improving soil properties. Soil additives, such as biostimulant products, have not proven to be consistently effective through research. The management challenge is to provide an urban environment that functions like the natural environment.

Key Words. Biostimulants; Bulk Density; Cation Exchange Capacity; Mechanical Resistance; pH; Soil Oxygen; Soil pH; Soil Salt; Soil Water; Temperature.
\end{abstract}

In urban and suburban areas, the soil environment often creates numerous challenges for tree root growth. Urban soil has been defined as, "a soil material having a non-agricultural, manmade surface layer more than $50 \mathrm{~cm}$ thick that has been produced by mixing, filling, or by contamination of land surface in urban and suburban areas" (Bockheim 1974). Urban soils are often highly altered from the natural state, and human activity is the primary agent of the disturbance. They generally have high vertical and spatial variability, modified and compacted soil structure, an impermeable crust on the soil surface, restricted aeration and water drainage, interrupted nutrient cycling, altered soil organism activity, presence of anthropogenic materials and other contaminants, and altered temperatures (Craul 1985; Bullock and Gregory 1991; Scheyer and Hipple 2005). These physical, chemical, and biological constraints of urban soils pose limitations for the growth of tree roots. Early experience gained working with the urban soils in Washington, D.C., and other difficult urban sites, led to the projection that about $80 \%$ of urban tree problems can be attributed to a poor soil environment, leading to synergistic effects of other debilitating urban stress factors producing an overall decline in plant vigor (Patterson et al. 1980).

The resources provided by the soil environment for root growth include adequate oxygen, water, and nutrients, non-limiting penetration resistance, acceptable $\mathrm{pH}$ range, and robust biological activity. Presence of contaminants or pathogens can be harmful to roots. Any one of these factors can limit root growth and development, even if all others are in adequate supply.

Urban environments are quite different from the natural environment to which trees are adapted, yet they must provide the same resources for growth if trees are to maintain a healthy balance between the crown (supplier and user of energy, user of nutrients and water) and root system (supplier of water and nutrients, user of energy). The management challenge is to provide an urban environment that functions like the natural environment, though its appearance may be different.

Recent reviews have described root architecture and rhizosphere ecology in the urban environment (Day et al. 2010a; Day et al. 2010b) and serve as a foundation for this review of research summarizing our current understanding of soil management techniques for urban trees. 


\section{SOILS INFLUENCE ROOT DEVELOPMENT}

Water, oxygen, mechanical resistance, temperature, soil reaction, cation exchange capacity, contaminants, and biology are soil factors that directly affect root growth. Water absorbed by plants transports nutrients and cools leaves through evaporation. Soil oxygen is essential for respiration in plant roots. Mechanical resistance physically limits root exploration of the soil (Letey 1985). Temperature controls certain metabolic processes in roots.

Water can be a dominant controlling factor, but all are interconnected. The influence of each factor on root growth will first be reviewed individually, followed by a review of their interactions. Because altering one factor does affect the quality of others, management practices to improve root growth will consider the effects on all factors together.

\section{Water}

The amount of water held in the soil is related to texture and structure. Sandy soils contain less than 10\% total water at field capacity. Clay soil can contain as much as $35 \%$ water, but more is unavailable to plant roots. The difference between the water content at field capacity and the water content at the permanent wilting point is the amount of available water.

Urban soils often have less structure and greater bulk density than most undisturbed natural soils. The resulting reduction in pore space reduces plant available water (Letey 1985; Craul 1992). The loss of natural soil structure is one of the most important limitations to tree growth in urban areas (Stewart and Scullion 1989).

\section{Measurement}

Assessment of soil moisture status in the root zone is necessary to determine the need for site improvements, such as improved drainage, or supplemental irrigation. Soil moisture can be measured by a variety of methods. The hand-feel method (Ross and Hardy 1997) is simple and fast. If the soil retains its shape after compression between the fingers, but is not sticky, the moisture content is favorable. This method can be prone to error since it requires experience and can be subjective. Determining gravimetric soil water is the most accurate, simple method not requiring special equipment. Soil is weighed before and after oven drying.
The most widely used and least-expensive waterpotential measuring device is the tensiometer. The tensiometer establishes a quasi-equilibrium condition with the soil water system through a porous ceramic cup. Electrical resistance blocks consist of electrodes encased in some type of porous material that reaches a quasi-equilibrium state with the soil. They are less sensitive in wet soils. Time-domain reflectometry and neutron scatter methods can be very precise, but require expensive, specialized equipment, and their use in arboriculture is primarily limited to research (World Meteorological Association 2008).

\section{Effect on Root Growth}

Fine root growth is slowed up to $90 \%$ by low soil water content (Barnett 1986; Walmsley et al. 1991; Kätterer et al. 1995; Torreano and Morris 1998; Meier and Leuschner 2008; Olesinski et al. 2011). Root growth decreases rapidly in most species when soil moisture is reduced to $10 \%-14 \%$ on an oven-dry basis (Newman 1966; Lyr and Hoffmann 1967) or $-50 \mathrm{kPa}$ soil moisture tension (Bevington and Castle 1985). This can result in a significant decrease of the root/shoot ratio (Blake et al. 1979; Meier and Leuschner 2008), especially during periods of active root growth (McMillin and Wagner 1995).

As soil begins to dry, the development of branch roots is inhibited more than the growth of primary roots (Wright et al. 1992). When roots are drought stressed, they mature rapidly toward the tip, decreasing absorption, and reducing future growth (Kaufmann 1968; Bilan 1974). As the effective absorbing surface is diminished, the roots do not regain their full capacity for water uptake until new root tips can be produced. When roots are rewatered immediately after cessation of elongation, roots may not resume elongation for at least one week. Resumption of root growth can take up to five weeks if water is withheld longer (Bilan 1974).

According to the optimal partitioning theory, plants should allocate relatively more carbon and nutrients to root growth than to aboveground growth when plant growth is limited by water shortage (Bloom et al. 1985). However, some research reports have shown a decrease in root length density when water is withheld (Ruiz-Canales et al. 2006; Abrisqueta et al. 2008). This decrease may be explained by increased fine-root turnover 
-higher fine-root mortality concurrent with increased root growth (Meier and Leuschner 2008).

In wet soils, the growth of roots tends to be confined towards the soil surface. In dry soils, root growth can be shifted downward due to water depletion in surface soils (Torreano and Morris 1998). When urban soils limit rooting depth, the ability of tree root systems to respond to periods of drought and high soil moisture may be very limited.

Flooding of soil usually leads to greatly reduced root growth, and death of many of the fine absorbing roots. The small root systems of flooded trees reflect the combined effect of reduction in root initiation and reduced growth of existing roots, as well as decay of the original root system. Because root growth is usually decreased more than shoot growth by high soil moisture, drought tolerance of flooded trees is reduced after the flood waters recede. This change reflects the inability of the small root systems to supply enough water to meet the transpirational requirements of the crown (Kozlowski 1985).

Responses of tree species to flooding vary widely (White 1973; Bell and Johnson 1974; Whitlow and Harris 1979). Tolerance can vary from only a few hours to many days or weeks, depending on the species, the organs directly affected, the stage of development, and external conditions, such as temperature. Roots are often more susceptible to oxygen deficiency than shoots (Vartapetian and Jackson 1997). Broadleaved trees as a group are much more flood-tolerant than conifers. Older trees usually tolerate flooding better than seedlings or saplings. Flooding during the dormant season is much less harmful than flooding during the growing season (Heinicke 1932). The greater injury and growth reduction by flooding during the growing season are associated with high oxygen requirements of growing roots with high respiration rates (Yelenosky 1963; Koslowski 1985).

\section{Aeration}

Respiration by plant roots and other soil organisms consumes oxygen and produces carbon dioxide. In unsaturated soils, the soil air connects directly with the aboveground atmosphere, but diffusion of gasses through the soil is slowed by water and soil particles. Oxygen concentrations decline and carbon dioxide concentrations increase with depth due to the oxy- gen demands of the roots, the soil fauna, fungi, and microbes. Oxygen deficiency in roots will be more likely to occur in warm soils than in cooler soils when reduced respiration is more balanced with diffusion rates (Yelenosky 1963; Armstrong and Drew 2002).

For most species, approximately $10 \%-12 \%$ oxygen in the soil atmosphere is needed for adequate root growth (Stolzy and Letey 1964; Tackett and Pearson 1964; Stolzy 1974; Valoras et al. 1964; Gilman et al. 1987; Mukhtar et al. 1996), and growth may cease at 5\% oxygen (Stolzy 1974). Soil carbon dioxide concentration can be damaging to roots when it reaches $0.6 \%$ (Gaertig et al. 2002).

For most species, root growth is reduced or stopped when the oxygen diffusion rate (ODR) drops below $0.2 \mu \mathrm{g} / \mathrm{cm}^{2} / \mathrm{min}$. Most plants are severely stressed between 0.2 and $0.4 \mu \mathrm{g} / \mathrm{cm} 2 / \mathrm{min}$. Above $0.4 \mu \mathrm{g} / \mathrm{cm}^{2} / \mathrm{min}$, plants grow normally (Stolzey and Letey 1964; Valoras et al. 1964; Lunt et al. 1973; Stolzy 1974; Erickson 1982; Blackwell and Wells 1983).

Redox potential can also be used as a measure of the oxygen status of the soil. Soil redox potentials of $400-700 \mathrm{mV}$ are generally considered well aerated. Root growth of most species is stopped at a soil redox potential of $350 \mathrm{mV}$, though roots of more water-tolerant species (e.g., Taxodium distichum) are able to grow until the redox potential reaches $200 \mathrm{mV}$ (Carter and Rouge 1986; Pezeshki 1991; Stepniewski et al. 1991).

Soil aeration is impacted by urban landscape features. In undisturbed, well-drained soil, oxygen and carbon dioxide contents can be near atmospheric levels close to the soil surface, decreasing most rapidly in the first $30 \mathrm{~cm}$ (Yelenosky 1963; Brady and Weil 1996). When not paved, vegetated and nonvegetated urban sites can be as well-aerated as forest stands (Gaertig et al. 2002). However, if topsoils are sealed or compacted, gas exchange between the soil and the atmosphere is interrupted (Gaertig et al. 2002). Oxygen content was reduced to $14.5 \%$ and carbon dioxide content was increased to $6 \%$ at $15 \mathrm{~cm}$ depth under an unpaved parking lot. The same levels were not reached until $90 \mathrm{~cm}$ depth in the adjacent undisturbed forest soil (Yelenosky 1963). In another study, there were minimal differences in soil oxygen between pavement and turf in the top $45 \mathrm{~cm}$ (Hodge and Boswell 1993). However, soil oxygen measurements were made only $75 \mathrm{~cm}$ from the edge of the 
pavement and oxygen could have diffused laterally from the nearby exposed soil. While it is commonly accepted that stone pavement with gaps allows for aeration of the soil, there was no difference in gas diffusivity between completely sealed surfaces (asphalt) and areas with flagstone or cobblestone with gaps in between (Weltecke and Gaertig 2012).

A water table less than $50 \mathrm{~cm}$ deep can reduce oxygen below levels considered sufficient to sustain vigorous root growth to within $5 \mathrm{~cm}$ of the soil surface (Callebaut et al. 1982). Elevated berm soils can be more aerated than surrounding soils at grade (Handel et al. 1997).

\section{Measurement}

Assessment of soil oxygen can be helpful in choosing the appropriate plant for the site, or understanding whether site modifications, such as improved drainage, may be necessary. However, measuring oxygen levels in the soil can be challenging: equipment can be expensive and suited primarily for research applications. Measurement at any moment in time may not reflect sustained conditions, and not all measurements provide the same information related to root growth.

Oxygen content, expressed as a percentage, is the amount of oxygen in the soil gases (the aboveground atmosphere contains $21 \%$ oxygen). ODR measures the rate at which oxygen can move through the soil to replace oxygen that is used by the root. ODR can be a better indicator of soil aeration (i.e., oxygen availability to roots) than oxygen content because it is possible to have a high soil oxygen concentration, but very low diffusion rate (MacDonald et al. 1993). The oxygen concentration in the soil atmosphere may not vary substantially at monitoring sites over time, or in response to changes in soil moisture. In contrast, ODR is strongly influenced by soil moisture and bulk density. Oxygen concentration was not consistently low enough to severely inhibit root function at sites where trees were declining. At the same time, ODR values within the root zones of declining trees were invariably in a range considered injurious to roots, while ODR values around vigorous trees were favorably high (Stolzy 1974; MacDonald et al. 1993).

Rusting pattern on steel rods can be used to assess soil anaerobism over an extended period
(Carnell and Anderson 1986; Hodge and Knott 1993; Hodge et al. 1993) and has been related to fine-root development of trees (Watson 2006a). Fine-root density in soils, where rust was present on over $60 \%$ of the steel rods, was generally three times greater than in soils with less than $25 \%$ rusting. This method can provide an indication of soil aeration over a period of months and up to a depth of $60 \mathrm{~cm}$ without the use of expensive equipment.

\section{Effect on Root Growth}

Growing root tips have high oxygen requirements, and fine-root density is often reduced when oxygen availability is low (Koslowski 1985; Gaertig et al. 2002; Weltecke and Gaertig 2012). In older parts of the root, the oxygen demand can be approximately half that of the tip (Armstrong and Drew 2002). Root dysfunction as a result of inadequate oxygenation can modify plant growth and development through interference in water relations, mineral nutrition, and hormone balance (Kramer and Kozlowski 1979; Armstrong and Drew 2002).

Species vary in their root system tolerance to low soil aeration. For example, loblolly pine (Pinus taeda) grew better at low aeration conditions (either high compaction or high water content) than ponderosa pine (Pinus ponderosa var. scopulorum) or shortleaf pine (Pinus echinata) (Siegel-Issem et al. 2005). Lists of species' tolerance to flooding, which reduces soil aeration, are available (White 1973; Bell and Johnson 1974; Whitlow and Harris 1979).

In some trees, such as willow (Salix), alder (Alnus), poplar (Populus), tupelo (Nyssa), ash (Fraxinus), baldcypress (Taxodium), and birch (Betula), oxygen can move down to the roots internally through intercellular spaces. This oxygentransporting tissue within roots is called aerenchyma. It is not uncommon in the subapical parts of wetland plant roots for as much as $60 \%$ of the root volume to be gas space for diffusion of oxygen from the shoot (Drew 1997; Armstrong and Drew 2002). Enough oxygen can be transported so that some is released into the soil immediately surrounding the roots (Hook et al. 1971; Armstrong and Read 1972).

\section{Mechanical Resistance}

Bulk density is a measure of dry mass per unit volume and used to describe limits to root growth in compacted soil. Soil strength, expressed as penetra- 
tion resistance, is a broader indicator of constraints on root growth that accounts for soil moisture, as well as bulk density (Baver et al. 1972; Gerard et al. 1982; Ehlers et al. 1983; Taylor and Brar 1991).

Parent material is the deepest and densest layer in the soil profile. As soils develop, formation of structure in the overlying horizons reduces bulk density. Clay deposition in the B horizon tends to fill existing pore spaces, making it denser as clay content increases (Foth 1990). Roots compact the soil nearby as they increase in size, and they also transmit the weight of the tree and forces generated by the wind onto the soil (Greacen and Sands 1980).

In urban and suburban settings, soil formation has been interrupted by removal, grading, mixing, or other disturbances. Thus, urban soils can have high bulk densities (Yang et al. 2005; Feng et al. 2008). Urban soil mean bulk density values of $1.6 \mathrm{~g} \mathrm{~cm}^{-3}$ have been reported, with individual values as high as $2.63 \mathrm{~g} \mathrm{~cm}^{-3}$ (Patterson 1977; Short et al. 1986; Jim 1998a; Jim 1998b). These levels of compaction restrict root growth for many woody species, especially in finer-textured soils.

Compaction occurs very quickly. On fine- to medium-textured soils, half of the increase in soil bulk density and soil strength occurred in the first two passes of traffic. Coarse soils were slightly more resistant to compaction (Brais and Camire 1998). Fine-textured soils are also slower to recover than coarse-textured soils (Page-Dumroese et al. 2006).

Soil on construction sites was heavily compacted to depths of 0.3-0.8 m (Randrup 1997). In a survey of areas to be landscaped near new residential and commercial construction, mean soil bulk density was found to be $1.56 \mathrm{~g} \mathrm{~cm}^{-3}$, which represents a $0.5 \mathrm{~g} \mathrm{~cm}^{-3}$ increase over adjacent undisturbed areas (Alberty et al. 1984). Bulk densities in fenced (undisturbed) areas ranged from 1.05 to $1.42 \mathrm{~g} \mathrm{~cm}^{-3}$, while in unfenced areas, bulk densities were 1.56 to 1.90 $\mathrm{g} \mathrm{cm}^{-3}$; often exceeding the $1.60 \mathrm{~g} \mathrm{~cm}^{-3}$ critical bulk density for the loam soils on the study site (Lichter and Lindsey 1994). In another study, the absence of differences between protected and unprotected areas was attributed to traffic occurring on areas not meant for traffic (Randrup and Dralle 1997).

\section{Measurement}

To determine bulk density, a soil core of known volume is oven dried at $105^{\circ} \mathrm{C}$ and weighed. Care is exercised in the collection of cores so that the natural structure of the soil is preserved. Any change in structure is likely to alter pore space and bulk density. Excavation methods are better for a gravelly soil. A quantity of soil is excavated, dried, and weighed, along with determining the volume of the excavation by filling the hole with sand of which the volume per unit mass is known, or water in a rubber liner (Grossman and Reinsch 2002).

Penetrometers are used to measure soil strength. Type of equipment used and soil moisture content will affect measurement. Penetrometers with 30-degree tips and diameter sizes of 12.8 and 20.3 $\mathrm{mm}$ are standard. The smaller cone size is for use in harder (more resistant) soils (American Society of Engineers 1992; Lowery and Morrison 2002).

Soil strength increases with bulk density and decreases with soil water content (Taylor and Burnett 1964; Eavis 1972; Blouin et al. 2008.) Finetextured soils are the most limiting (Gerard et al. 1982), but penetration resistance can be affected more by water content than by texture. Penetration resistance in a dry soil $(-1500 \mathrm{kPa})$ exhibited a maximum at clay content of $35 \%$, while in a moist soil $(-10 \mathrm{kPa})$ penetration resistance was minimally affected by texture (Vaz et al. 2011).

\section{Effect on Root Growth}

The bulk density that limits root growth varies with soil texture (as reviewed in Daddow and Warrington 1983) and soil moisture (Day et al. 2000). Greater development of structure in finetextured soils accounts for their lower bulk density as compared to coarse-textured soils. A bulk density of $1.60 \mathrm{~g} \mathrm{~cm}^{-3}$ would be limiting in a clay loam, but not in a sandy loam (Foth 1990). Summary tables (Jones 1983; Daddow and Warrington 1983; NRCS Soil Quality Institute 2000 (Table 1) are consistent with reports of root restriction in individual tree species (Minore et al. 1969; Chiapperini and Donnelly 1978; Webster 1978; Zisa et al. 1980; Heilman 1981; Tworoski et al. 1983; Alberty et al. 1984; Pan and Bassuk 1985; Simmons and Pope 1985; Reisinger et al. 1988; Watson and Kelsey 2006).

Reconstruction of soil profiles from six forest sites in greenhouse tests showed root and shoot growth in soil from lower horizons $(10-30 \mathrm{~cm})$ averaged only $41 \%$ of that in topsoil, a significantly greater restriction of growth than that achieved through 
Table 1. General relationship of soil bulk density to root growth based on soil texture (adapted from NRCS Soil Quality Institute 2000).

\begin{tabular}{lll}
\hline Soil texture & $\begin{array}{l}\text { Ideal bulk densities } \\
\left(\mathrm{g} \mathrm{cm}^{-3}\right)\end{array}$ & $\begin{array}{l}\text { Bulk densities that may affect } \\
\text { root growth }\left(\mathrm{g} \mathrm{cm}^{-3}\right)\end{array}$ \\
\hline Sands, loamy sands & $<1.60$ & 1.69 \\
Sandy loams, loams & $<1.40$ & 1.63 \\
Sandy clay loams, clay loams & $<1.40$ & 1.60 \\
Silts, silt loams & $<1.30$ & 1.60 \\
Silt loams, silty clay loams & $<1.10$ & 1.55 \\
Sandy clays, silty clays, some & $<1.10$ & 1.49 \\
clay loams (35\%-45\% clay) & $<1.10$ & \\
Clays (>45\% clay) & & 1.39 \\
\hline
\end{tabular}

compaction of up to $0.17 \mathrm{~g} \mathrm{~cm}^{-3}$ greater than the undisturbed field sites (25\%). Topsoil displacement and profile disturbance may be more damaging than soil compaction (Williamson and Neilsen 2003).

Soil strength, not bulk density, was found to be the critical impedance factor controlling root penetration (Taylor and Burnett 1964; Zisa 1980). Reduced survival and growth of sugar maple (Acer saccharum 'Seneca Chief') and callery pear (Pyrus calleryana 'Redspire') in compacted soil were due to mechanical impedance, rather than limited aeration and drainage (Day et al. 1995). The critical limit of soil strength above which woody plant roots will likely be greatly restricted is $2.5 \mathrm{MPa}$ when measured with a standard penetrometer (Taylor et al. 1966; Greacen and Sands 1980; Zisa et al. 1980; Ball and O'Sullivan 1982; Abercrombie 1990; Day and Bassuk 1994; Blouin et al. 2008).

Root growth decreases as compaction and soil strength increase (Youngberg 1959; Taylor et al. 1966; Sands et al. 1979; Bengough and Mullins 1990; Jordan et al. 2003; Blouin et al. 2008). Both controlled studies (Minore et al. 1969) and field observations (Forristall and Gessel 1955) have shown that the capacity for root growth in compacted soil often varies among plant species. For example, root growth of Siberian larch (Larix sibirica), English oak (Quercus robur), western red cedar (Thuja plicata), and Formosa acacia (Acacia confusa) were little affected by soil bulk density as high as $1.89 \mathrm{~g} \mathrm{~cm}^{-3}$, while Norway spruce (Picea abies), Douglas fir (Pseudotsuga menziezii), littleleaf linden (Tilia cordata), and tallow lowrel (Litsea glutinosa) were the least capable of growing roots in compacted soil (Forristall and Gessel 1955; Korotaev 1992; Liang et al. 1999). As little as 0.14 $\mathrm{g} \mathrm{cm}^{-3}$ can make a difference (Minore et al. 1969).

Soil compaction can affect root distribution. Root penetration depth can be restricted by soil bulk density (Halverson and Zisa 1982; Nambiar and Sands 1992; Laing et al. 1999). If not all parts of a root system are equally exposed to compaction, compensatory growth by unimpeded parts of the root system may compensate, and the distribution but not the total length of roots may be altered (Unger and Kaspar 1994).

Individual root tips can penetrate only those soil pores that have a diameter greater than that of the root. Roots often grow into root channels from previous plants, worm channels, structural cracks, and cleavage planes, thereby tapping a larger reservoir of water and mineral nutrients. In very compacted soils, root growth may be confined almost entirely to these pores and cracks (Taylor et al. 1966; Eis 1974; Patterson 1976; Gerard et al. 1982; Ehlers et al. 1983; Hullugalle and Lal 1986; Wang et al. 1986; Bennie 1991; van Noordwijk et al. 1991). If not present, roots may undergo redirection of growth from deeper layers toward uncompacted surface soil when downward growth is restricted by high bulk density (Waddington and Baker 1965; Heilman 1981; Gilman et al. 1987). The net result is the proliferation, if not concentration, of roots at a shallow depth (Gilman et al. 1982; Weaver and Stipes 1988; Jim 1993a). Such a shallow root system will be more affected when surface soils dry during periods of drought.

There is a tendency to form more lateral roots with increasing soil strength (Gilman et al. 1987; Misra and Gibbons 1996). Length of primary and lateral roots of shining gum (Eucalyptus nitens) was reduced $71 \%$ and $31 \%$, respectively, with an increase in penetrometer resistance from 0.4 to 4.2 MPa. High mechanical resistance will also tend to increase the root diameter behind the root tip (Taylor et al. 1966; Eavis 1972; Russell 1977; Bengough and Mullins 1990; Misra and Gigbons 1996), and the growth and shape of 
root cells are altered (Pearson 1965). Differences among species in their ability to penetrate strong soil layers appear to be due to differences in root diameter (Clark et al. 2003).

\section{Temperature}

Urban soils can be warmer due to surrounding pavements and lack of vegetation cover. Unvegetated playground soils in Central Park (New York City, New York, U.S.) were $3.13^{\circ} \mathrm{C}$ warmer than an adjacent wooded area (Mount et al. 1999). Maximum summer soil temperatures under pavement in the northern United States were $32^{\circ} \mathrm{C}-34^{\circ} \mathrm{C}$, and up to $10^{\circ} \mathrm{C}$ warmer than nearby unpaved areas (Halverson and Heisler 1981; Graves and Dana 1987). In Texas, U.S., summer soil temperatures under pavement exceeded $48^{\circ} \mathrm{C}, 10^{\circ} \mathrm{C}$ warmer than unpaved areas, and remained above $35^{\circ} \mathrm{C}$ for all but a short time at night. Temperatures are highest under dark pavements (Arnold and McDonald 2009).

\section{Effect on Root Growth}

Biological activity in the soil, and therefore root growth, varies with temperature (Lloyd and Taylor 1994). Root growth occurs over a wide range of temperatures, but is much slower at low and high temperatures. Reported minimum temperatures for root growth range from $2^{\circ} \mathrm{C}$ to $11^{\circ} \mathrm{C}$ (Lyr and Hoffmann 1967; Solfjeld and Pedersen 2006). Sugar maple (Acer saccharum) roots began to grow in spring as soils warmed to $5^{\circ} \mathrm{C}$, but initial root growth may be quite slow at such low temperatures. Active root growth has been reported to begin when soil temperatures reach $10^{\circ} \mathrm{C}-15^{\circ} \mathrm{C}$ (Nambiar et al. 1979; Carlson 1986; Harris et al. 1995; Solfjeld and Pedersen 2006). Optimum temperatures for root growth have been reported at $18^{\circ} \mathrm{C}-32^{\circ} \mathrm{C}$ (Lyr and Hoffman 1967; Larson 1970; Nambiar et al. 1979; Struve and Moser 1985; Headley and Bassuk 1991; Harris et al. 1995; Solfjeld and Pedersen 2006; Richardson-Calfee et al. 2007).

The high temperature at which root injury begins to occur is around $34^{\circ} \mathrm{C}$ (Graves and Wilkins 1991; Graves 1994; Graves 1998; Wright et al. 2007). Roots of most woody species are killed at $40^{\circ} \mathrm{C}-50^{\circ} \mathrm{C}$ (Wong et al. 1971). Maximum temperatures for active growth have been reported at $25^{\circ} \mathrm{C}-38^{\circ} \mathrm{C}$, depending on the species (Proebsting 1943; Wong et al. 1971; Gur et al. 1972; Graves et al. 1989a; Graves et al. 1989b; Graves 1991; Martin and Ingram 1991; Graves and Aiello 1997; Arnold and McDonald 2009). Direct heat injury of roots can occur when the soil remains above $32^{\circ} \mathrm{C}$ for extended periods of time (Graves 1998), and the longer the duration of high temperatures, the more root growth is reduced (Graves et al. 1989b; Graves and Wilkins 1991). Honeylocust (Gleditsia triacanthos) is the only temperate tree species reported to sustain growth at root-zone temperatures above $32^{\circ} \mathrm{C}$ (Graves et al. 1991).

The root tissues of most woody plants can be killed at soil temperatures of $-5^{\circ} \mathrm{C}$ to $-20^{\circ} \mathrm{C}$ (Havis 1976; Studer et al. 1978; Santamour 1979; Pellett 1981; Lindstrom 1986; Bigras and Dumais 2005), although roots of black spruce (Picea mariana) were not affected by temperatures as low as $-30^{\circ} \mathrm{C}$ (Bigras and Margolis 1996). Young roots are less freeze-tolerant than mature roots (Bigras and Dumais 2005).

\section{Soil pH}

Plant performance is strongly affected by nutrient availability, which in turn is influenced by soil $\mathrm{pH}$ (acidity or alkalinity). Most nutrients are available at optimal levels in slightly acid to neutral soils ( $\mathrm{pH}$ between 5.5 and 7.2), and trees generally grow best in this $\mathrm{pH}$ range. Soil $\mathrm{pH}$ can be measured with electronic meters or colorimetric tests based on color of solutions or strips.

Urban soils tend to have higher soil $\mathrm{pH}$ than their natural counterparts. In Berlin, Germany, a $\mathrm{pH}$ of 8 was observed streetside, compared to a $\mathrm{pH}$ of less than 4 within a forest a short distance from the street (Chinnow 1975). Over half of soils sampled in Hong Kong, China, were rated strongly ( $\mathrm{pH} 8.5-9)$ to very strongly ( $\mathrm{pH} 9-9.5$ ) alkaline, while surrounding soils were acidic at $\mathrm{pH} 4-5$ (Jim 1998b). Streetside soils of Syracuse, New York, U.S., had a pH range of 6.6 to 9.0 with an average of about 8.0 (Craul and Klein 1980). Urban soils of Philadelphia, Pennsylvania, U.S., ranged from 3.7 to 9.0 with a mean of 7.6 (Bockheim 1974).

Elevated $\mathrm{pH}$ values have been attributed to the application of calcium or sodium chloride as road and sidewalk deicing compounds in northern latitudes, irrigation with calcium-enriched water (Bockheim 1974), and the surface weathering of concrete and limestone buildings and sidewalks (Bockheim 1974; Messenger 1986; Okamoto and Maenaka 2006). 


\section{Effect on Root Growth}

The effects of $\mathrm{pH}$ on root growth are primarily related to nutrient availability. Some nutrients, such as iron and manganese, become less available in alkaline soils $(\mathrm{pH}$ above 7.2) because of chemical changes caused by the alkalinity. Other nutrients, such as phosphorous, become less available in highly acid soils ( $\mathrm{pH}$ less than 5.5). When the $\mathrm{pH}$ is 4.5 or less, aluminum toxicity can restrict root growth (Foth 1990; Jim 1993b). In most plant systems, aluminum toxicity has a direct effect on root growth by inhibiting cell division in the root apical meristem (Kochian 1995).

A nutrient deficiency caused by sub-optimum soil $\mathrm{pH}$ could actually stimulate root growth in order to explore larger volumes of soil to acquire additional nutrients and alleviate deficiency symptoms (Ingestad and Lund 1979; Ericssson and Ingestad 1988).

\section{Cation Exchange Capacity}

Cation exchange capacity (CEC) is a measure of the nutrient-holding (adsorption) power of the soil. Once adsorbed, cationic minerals are not easily lost when the soil is leached by water and therefore provide a nutrient reserve for plant roots. CEC is highly dependent upon soil texture and organic matter content. In general, the more clay and organic matter in the soil, the higher the CEC. Small clay soil particles have a large, negatively charged surface area for their size and hold relatively large amounts of ions. Organic matter particles have even more negative surface charges on the surface than clay for nutrient exchange. Sandy soils have low CEC due to their low organic matter and clay content.

$\mathrm{CEC}$ is usually greatest at the surface where organic matter accumulates. Increasing clay with depth can act to counterbalance the decrease in organic matter and reduction of CEC. The CEC of most soils increases with pH (Craul 1992; Brady and Weil 1996).

CEC is determined by laboratory testing, and methods vary with the soil type. Reported urban soil CEC values have been 5-12 cmol/ $\mathrm{kg}$ (Short et al. 1986; Jim 1998b). Normal values vary, from $5 \mathrm{cmol} / \mathrm{kg}$ to $25 \mathrm{cmol} / \mathrm{kg}$, depending on texture, organic matter content, and $\mathrm{pH}$ (Foth 1990; Landon 1991; Brady and Weil 1996).

\section{Contaminants}

Salt in soil inhibits plant water uptake by lowering the osmotic pressure of soil water (Prior and Berthouex 1967). This reduces the water uptake of trees and symptoms of decline mimic those of drought (Herrick 1988). Once salt enters the roots, it upsets the osmotic balance within root cells (Janz and Polle 2012) and is toxic to the endomycorrhizae (Guttay 1976). The increased sodium on the cation exchange sites also breaks down soil structure (Holmes 1961; Hutchinson and Olson 1967), decreasing the permeability and water-holding capacity of the soil. All of these factors may contribute to a decline in tree health.

Damage from salt-contaminated soil occurs frequently in urban areas where large amounts of salt are used for deicing roads and pavements. Sodium chloride is the most common deicer applied. Parkways, street tree planter boxes, highway medians, and roadsides are locations where soil accumulation of deicing salts is highest. Sodium levels were 5.4 times higher and chloride was 15 times higher in the center of newly installed, narrow, raised medians along an urban highway after one winter, compared to the center of wide medians along the same roadway. The high levels were attributed to proximity to high speed traffic and its associated spray and splash (Hootman et al. 1994). Elevated levels of sodium have been reported in the soil up to $30 \mathrm{~m}$ from the highway and elevated levels of soil chlorine to a distance of $61 \mathrm{~m}$ (Langille 1976; Hofstra et al. 1979; Simini and Leone 1986). In contrast, rural highway studies show salt levels decline rapidly with distance to pavement (Herrick 1988; Cunningham et al. 2008). The release of salts from rapid-release forms of fertilizer can also elevate soil salt levels (Jacobs et al. 2004).

Reclaimed wastewater (RWW) and groundwater used to irrigate urban plantings in arid climates can be highly saline. Sodium and chloride are the major chemical constituents in RWW that are potentially detrimental to plants (State of California 1978; Schaan et al. 2003). Compared with sites irrigated with surface water, sites irrigated with RWW exhibited up to $187 \%$ higher electrical conductivity (EC) and 481\% higher sodium adsorption ratio (SAR) (Qian and Mecham 2005; Schuch et al. 2012). Soil types play a role on soil salinization as much as 
water quality. The highest salinity was found in clay and the lowest in sand (Miyamoto 2012).

The best method for assessing soil salinity is to measure the electrical conductivity of soil solution extracts. Conductivity of $2 \mathrm{dS} / \mathrm{m}$ (deci-Siemens/ meter) is considered harmful to salt-sensitive plants (Foth 1990; Jacobs and Timmer 2005). All but very salt-tolerant plants will be affected at $4 \mathrm{dS} / \mathrm{m}$. Czerniawska-Kusza et al. (2004) found necrosis and chlorosis in leaves at levels of $132 \mu \mathrm{g} \mathrm{Na} / \mathrm{g}$ of soil. Soil chloride ion concentrations of up to $200 \mu \mathrm{g} / \mathrm{g}$ are not considered harmful to plants (Jim 1998a).

Deicing salt can cause the death of surface roots in roadside trees (Wester and Hohen 1968; Krapfenbauer et al. 1974; Guttay 1976; Jacobs et al. 2004; Madji and Persson 1989), though the risk of root damage associated with salt concentrations levels appears to be dependent on species, age of root system, and soil moisture availability (Jacobs and Timmer 2005). Damage may result from osmotic and/or specific ion effects (Dirr 1975). Root rot caused by Phytophthora sp. can increase with soil salinity as well (Blaker and MacDonald 1985; Blaker and MacDonald 1986). Indirect damage occurs when sodium displaces other ions from soil cation exchange sites reducing their availability, and breaks down soil structure leading to soil compaction (Herrick 1988; Dobson 1991; Hootman et al. 1994).

Trees growing in soils with high salt levels tended to have more twig dieback and less twig growth than those growing in soils with lower salt levels (Berrang et al. 1985). Sodium chloride and other salts accumulating in the root zone may instigate and exacerbate street tree decline (Hootman et al. 1994).

Heavy metals is a term generally used to describe a group of metallic elements that can be toxic to plants and animals. Some, such as copper, molybdenum, and zinc are essential trace elements, but excessive levels can be toxic (Prasad 2004). Heavy metal contamination tends to be greater toward the city center and in areas of commercial and industrial land use (Carey et al. 1980; Blume 1989; Wang and Zhang 2004). City center and wasteland soils generally had enhanced heavy metal concentrations to at least $30 \mathrm{~cm}$ depth (Linde et al. 2001). Soils on the National Mall in Washington, D.C., U.S., had elevated levels of lead, zinc, nickel, copper, and cadmium (Short et al. 1986). Concentrations of heavy metals in roadside soils decrease with distance from traffic and depth in the soil profile. The contamination has been related to the composition of gasoline, motor oil, and car tires, and to roadside deposition of the residues of these materials (Lagerwerf and Specht 1970; Madji and Persson 1989). Long-term sewage sludge application may result in the accumulation of $\mathrm{Zn}, \mathrm{Cu}$, and $\mathrm{Ni}$ in the soil and plant (Bozkurt et al. 2010).

Soil heavy-metal data has been published for several cities (Lagerwerf and Specht 1970; Carey 1980; Blume 1989; Jim 1998a). Levels of many elements were higher on urban sites than suburban and rural sites up to 10 times or more. No plant damage was reported with these higher levels.

\section{Soil Biology}

Soil organisms are an important component of a healthy soil that promotes root growth. The ratio of fungal to bacterial biomass is often near 1:1 in grass and agricultural soil ecosystems. With reduced disturbance, fungi become more plentiful, and the ratio of fungi to bacteria increases over time. Forests tend to have fungal-dominated microflora. The ratio of fungal to bacterial biomass may be $5: 1$ to $10: 1$ in deciduous forests and 100:1 to 1000:1 in coniferous forests (Soil and Water Conservation Society 2000). Assessing abundance of soil bacteria and fungi and mycorrhizal colonization of roots requires extensive skill and laboratory equipment.

The zone of soil adjacent to plant roots with a high population of microorganisms is the rhizosphere. Bacteria feed on sloughed-off plant cells and the proteins and sugars released by roots. The protozoa and nematodes that "graze" on bacteria are also concentrated near roots. Thus, much of the nutrient cycling and disease suppression needed by plants occurs immediately adjacent to roots (Soil and Water Conservation Society 2000). Rhizosphere $\mathrm{pH}$ can be up to two units different than the rest of the soil (Marschner and Römbeld 1996).

Mycorrhizae are symbiotic relationships that form between common soil fungi and plants. The benefits of mycorrhizal associations of tree roots are well established (Smith and Read 1997). The fungi colonize the root system of a host plant, providing increased nutrient absorption capabilities, while the plant provides the fungus with carbohydrates from photosynthesis. Mycorrhizae offer the host plant increased protection against certain pathogens. 
Urban planting sites are often considered to be of poor soil quality, but mycorrhizal inoculum (spores) was more abundant in urban soil than in forest soil in one study (Wiseman and Wells 2005). Some mycorrhizal fungi colonizing littleleaf linden (Tilia cordata) roots were common to both street trees and forest trees. Others were not. Colonization levels were high on both street and forest trees (Nielsen and Rasmussen 1999; Timonen and Kauppinen 2008). Native desert trees had greater colonization by arbuscular mycorrhizal fungi (AMF) than residential landscape trees, and AMF species composition differed at the two site types (Stabler et al. 2001).

\section{Interdependence of Soil Factors}

As a result of the interdependence of soil properties, the status of one soil factor can have an effect on all others; an understanding of their interrelationships is important for proper management.

\section{Water and Air}

Increasing soil moisture reduces soil aeration when water replaces the air normally held in the pores of the soil. Water slows the diffusion of oxygen to $1 / 10,000$ of that in air, and it reduces its concentration to about $1 / 32$ of that in air. The net result is an effective resistance to flow that is around 320,000 times greater in saturated soil than that of air (Armstrong and Drew 2002).

\section{Water and Compaction}

Compaction can decrease the number of days of available water in clay-loam soil. However, compaction can increase the number of days that water is available in a sandy loam soil (Gomez et al. 2002).

Tree roots can grow successfully in significantly compacted soils provided soil moisture is readily available (Zisa et al. 1980; Pittenger and Stamen 1990; Bulmer and Simpson 2005; Siegel-Issem et al. 2005). Resistance to penetration in a clay loam soil was found to decrease from 3.5 $\mathrm{MPa}$ (limiting) to $2.1 \mathrm{MPa}$ (non-limiting) when volumetric soil moisture increased from approximately 27\% to $40 \%$ (Day et al. 1995). Roots of spotted gum (Corymbia maculata) and red-flowering gum (C. ficifolia) were able to penetrate soil compacted to a bulk density of $1.6 \mathrm{~g} \mathrm{~cm}^{-3}$ at $7 \%$ soil moisture, but when moisture was increased to $10 \%$ roots could penetrate soils of $1.8 \mathrm{~g} \mathrm{~cm}^{-3}$ (Smith et al. 2001).
Species can vary in their ability to capitalize on reduced penetration resistance of wet soils. Silver maple (Acer saccharinum) roots can grow in moderately compacted soil when high soil water content decreases soil strength, even though aeration is low, whereas dogwood (Cornus florida) roots are unable to grow under the same low aeration conditions (Day et al. 2000).

\section{Air and Compaction}

One of the main effects of high bulk density is a restricted oxygen supply (Yelenosky 1963; Yelenosky 1964; Rickman et al. 1966). Oxygen is less restricted when the soil is dry and less pore space is filled with water (Day 1995). Oxygen diffusion rate was lowest in soils with high bulk density (MacDonald et al. 1993). Compaction from a bulk density of $1.04 \mathrm{~g} \mathrm{~cm}^{-3}$ to $1.54 \mathrm{~g} \mathrm{~cm}^{-3}$ reduced gas diffusion by $38 \%$ when soil was dry. In wet soil, however, compaction reduced diffusion by $82 \%$ (Currie 1984).

Plant response to oxygen level has been shown to interact with mechanical impedance (Gill and Miller 1956). In general, soil compaction can have a strong inhibitory effect on root penetration when the oxygen level is high, but no significant effect at a low oxygen level because root growth is already reduced by lack of aeration (Tackett and Pearson 1964; Hopkins and Patrick 1969; da Silva and Kay 1997).

Anaerobic conditions are likely to limit root growth in compacted fine-textured and poorly drained soils, whereas mechanical impedance is more likely to limit root growth in compacted coarsetextured and well-drained soils (Webster 1978).

\section{Soil Conditions and Root Disease}

Poorly aerated and poorly drained soil can increase incidence of soil-borne diseases. Root diseases are favored when soils are water-saturated (Hansen et al. 1979). Saturated soil and low oxygen supply causes a reduction in root initiation, growth of existing roots, and an increase in decay of roots, largely as a result of invasion of Phytophthora sp. Fungi, which tolerate low soil aeration (Stolzy et al. 1965; Sena Gomes and Kozlowski 1980; Blaker and McDonald 1981; Benson et al. 1982; Stolzy and Sojka 1984; Benson 1986; Duniway and Gordon 1986; Gray and Pope 1986; Ownley and Benson 1991). Armillaria root disease, also known as shoestring root rot, causes most damage on trees that are stressed 
by one or more abiotic or biotic factors. These may include drought, soil compaction, and other soil problems common on urban sites (Worall 2004).

\section{Root Development and Nutrient Uptake}

When soil factors limit root development there can be a direct impact on nutrient uptake. Nutrient deficiencies can occur when there is insufficient uptake by the roots and use by the crown. If improved soil conditions allow the root system to expand and explore a larger soil volume and supply of nutrients, the tree may overcome the deficiency and symptoms may dissipate (Ingestad and Lund 1979; Ericssson and Ingestad 1988).

\section{MANAGEMENT PRACTICES TO IMPROVE THE SOIL ENVIRONMENT}

The effectiveness of management practices to enhance soil as a medium for root growth can affect all soil factors and is influenced by soil physical properties. Soils classified as having poor physical conditions are those that require very careful management to maintain conditions favorable for root growth. Soils with good physical conditions require less careful management (Letey 1985).

\section{Prevention}

Prevention of soil compaction is preferred. Treatments to alleviate compaction can be expensive, difficult to apply, sometimes ineffective, and may injure roots (Howard et al. 1981). When only acted upon by natural forces, return to the initial, uncompacted state is slow (Hatchell et al. 1970; Froehlich and McNabb 1984; Froehlich et al. 1986; Corns and Maynard 1998; Stone and Elioff 1998; Blouin et al. 2005). Fine-textured soils are slower to recover than coarse-textured soils. Surface soils will recover most rapidly (Page-Dumroese et al. 2006). When compaction severely reduced soil aeration and root growth after a logging operation, after 14 years, recovery was limited to the top $4 \mathrm{~cm}$ of soil. After 18 years, recovery reached a depth of $18 \mathrm{~cm}$. Only after 24 years was recovery detected throughout the rooting zone (von Wilpert and Schaffer 2006). Factors, such as a fluctuating water table, freeze-thaw cycles (Fleming et al. 1999; Stone and Kabzems 2002), and vegetation regrowth (Page Dumroese et al. 2006), may accelerate a bulk density decrease.
Mulch or gravel over geotextile can prevent soil compaction during construction. In contrast, plywood did not protect the underlying soil from compaction (Donnelly and Shane 1986; Lichter and Lindsey 1994). Fencing can be an effective way to prevent soil compaction on a construction site (Lichter and Lindsey 1994), but must be monitored and maintained to be effective (Randrup and Dralle 1997).

\section{Amendments}

The use of organic amendments, such as biosolids, animal manure, or compost, generally reduces the bulk density of compacted soils (Cogger 2005; Garcia-Orene et al. 2005), although this is not always the case (Patterson 1977). The proposed mechanisms for this phenomenon are that the high density substrate is simply being diluted with a low-density material (the amendment) or that the amendment physically increases porosity (Clapp et al. 1986; Cogger 2005). Organic amendments can increase root growth (Beeson and Keller 2001; Davis et al. 2006), microbial activity (van Schoor et al. 2008) and CEC. Composted organic matter is most effective, as the humus component has the greatest CEC. Incorporation of certain types of biochar can increase CEC (Chan et al. 2007; Laird et al. 2010), but research on this topic is still limited.

Inorganic soil amendments have been used to improve soil properties and resist compaction. Sintered fly-ash and expanded slate amendments resulted in lower bulk densities and increased pore space after being incorporated into the soil (Patterson 1977). Amendment with mixtures of gravel, expanded clay, and lava rock improved the soil aeration and soil moisture in clay loam and silty loam soils (Braun and Fluckiger 1998). These studies did not assess the effect of soil changes on root systems performance.

Hydrophilic polymer gels (hydrogels) are sometimes added to the soil to increase available water. Research has not shown that the use of hydrogels can consistently increase root growth of trees (Hummel and Johnson 1985; Keever et al. 1989; Tripepi et al. 1991; Walmsley et al. 1991; Winkelmann and Kendle 1996; Huttermann et al. 1999; Gilman 2004; Abbey and Rathier 2005). 


\section{Cultivation}

Cultivation has been used with mixed results to improve soil properties and promote tree root development. Deep cultivation by ripping prior to planting decreased bulk density and soil penetration resistance (Rolf 1991; Rolf 1993; Moffat and Boswell 1997; Lincoln et al. 2007) and increased both the maximum root depth and total number of roots compared with the untreated control for Italian alder (Alnus cordata), Japanese larch (Larix kaempferi), Austrian pine (Pinus nigra), and European white birch (Betula pendula) (Sinnett et al. 2008). In other cases, ripping had no effect on rooting depth (Nieuwenhuis et al. 2003) or was reported to be effective for less than a year (Moffat and Boswell 1997).

There was no reduction in soil strength from surface soil cultivation with an air excavation tool after one year on three of four sites. Compost incorporation with air cultivation did result in a reduction of soil strength that persisted for at least three years (Fite et al. 2011).

Cultural techniques that improve soil tilth, aeration, and drainage reduce conditions favorable to root disease (Juzwik et al. 1997), and also improve host resistance by reducing or avoiding stress associated with anaerobic conditions (Sutherland 1984).

\section{Mulch}

The benefits of organic mulch are well established (Chalker-Scott 2007) and continue to be reinforced. A review of published mulch research studies showed surface mulch improved soil physical properties and tree physiology, but there was no improvement in chemical or biological properties (Scharenbroch 2009). Improvement of soil properties will enhance root growth.

Over time, organic mulches can reduce soil bulk density (Donnelly and Shane 1986; Cogger et al. 2008) and increase organic matter content (Watson et al. 1996; Johansson et al. 2006; Fite et al. 2011). Mulch can increase water infiltration (Donnelly and Shane 1986; Cogger et al. 2008), reduce evaporation from the soil surface, and increase moisture availability (Litzow and Pellett 1983; Iles and Dosmann 1999; Arnold et al. 2005; Cogger et al. 2008; Singer and Martin 2008; Fite et al. 2011). Mulch allowed a 50\% reduction in irrigation while still maintaining acceptable growth and appearance (Montague et al. 2007). Mulch also insulates soil from temperature extremes (Montague et al. 1998; Iles and Dosmann 1999; Singer and Martin 2008). In December, soil under mulch was $6^{\circ} \mathrm{C}$ warmer than exposed sod or bare soil (Shirazi and Vogel 2007). In temperate climates, the soil may warm more slowly if new mulch is applied before the soil warms in spring (Myers and Harrison 1988).

Organic surface mulch generally improves shoot and root growth (Kraus 1998; Ferrini et al. 2008; Arnold and McDonald 2009; Scharenbroch 2009). Adding wood chip mulch to the surface of red maple (Acer rubrum) and sugar maple (A. saccharum) grown in sandy loam and clay loam, respectively, increased growth above- and belowground (Fraedrich and Ham 1982). Mulching with wood chips can result in a 30\%-300\% increase in fine-root development in the top $15 \mathrm{~cm}$ of soil (Fraedrich and Ham 1982; Green and Watson 1989; Himelick and Watson 1990). Mulches may not be beneficial for some desert plants (Singer and Martin 2009).

When a mulch layer is maintained for several years, a partially decomposed organic layer develops that holds moisture and minimizes evaporation from the soil beneath. A dense mat of roots can form in the layer of mulch as well as in the soil beneath it (Bechenbach and Gourley 1932; Watson 1988). The roots in the mulch will not be at any greater risk of desiccation, since the well-established mulch layer can hold more water than the soil itself, without decreasing aeration to the soil beneath it (Watson 1988; Himelick and Watson 1990). Mulch reduces root competition for soil moisture and nutrients from lawn grasses (Richardson 1953; Gilman 1989; Kraus 1998). In addition to competition for water and nutrients, some lawn grasses may be able to reduce the growth of the trees through production of allelopathic chemicals. Root growth of forsythia (Forsythia intermedia) was suppressed by ryegrass and red fescue leachates (Fales and Wakefield 1981). Fescues have also been shown to stunt the growth of southern magnolia (Magnolia grandiflora) (Harris et al.1977), river redgum (Eucalyptus camaldulensis) (Meskimen 1970), black walnut (Juglans nigra) (Todhunter and Beineke 1979), and sweetgum (Liquidambar styraciflua) (Walters and Gilmore 1976), but specific effects on root systems were not reported. 
While mulching has many benefits for soil quality and root health, there are some potential drawbacks. One concern about mulching is that it creates conditions ideal for certain disease-causing fungi. Fraedrich and Ham (1982) did not find any enhancement of the soil-borne pathogenic fungi, Pythium spp. and Fusarium spp. during their one-year study. Austrian pine saplings that were mulched with fresh needles and shoot tips from Sphaeropsis tip blight diseased trees developed more than twice the percentage of blighted tips. There was no Botryosphaeria canker or Armillaria root rot disease development when redbud (Cercis canadensis) and red oak (Quercus rubra) saplings, respectively, were mulched with wood chips from diseased trees (Jacobs 2005). A decrease in growth the first year after mulching, and an increase in the second year has been attributed to nitrogen immobilization in the first year followed by release the next (Hensley et al. 1988; Truax and Gagnon 1993; Erhart and Hartl 2003).

A layer of mulch can intercept rain water before it reaches the roots if the amount of water is small or the mulch is thick (Gilman and Grabosky 2004; Arnold et al. 2005; Johansson et al. 2006). Although $25 \mathrm{~cm}$ or more of coarse textured organic mulch does not adversely affect soil oxygen or fine root development (Watson and Kupkowski 1991; Greenly and Rakow 1995), as little as $5 \mathrm{~cm}$ of finetextured organic mulch, or compost, can reduce soil oxygen to less than $10 \%$ under wet conditions, which can affect root function (Hanslin et al. 2005).

\section{Aeration}

Compressed air soil injection treatments have generally been ineffective in relieving compaction or increasing soil aeration (Yelenosky 1964; Smiley et al. 1990; Hodge 1991; MacDonald et al. 1993; Rolf 1993). Soil texture may have a strong influence on the results. Reports of success in reducing bulk density or increasing porosity were in loamy soils (Rolf 1993; Lemaire et al. 1999).

A traditional approach to aeration of compacted soil around trees is vertical mulching (i.e., drilling a pattern of holes in the root zone soil). Research on vertical mulching has provided mixed results. Holes $5 \mathrm{~cm}$ diameter, $45 \mathrm{~cm}$ deep, with or without sand-bark mix backfill, provided no benefit to Chinese wingnut trees (Pterocarya stenoptera)
(Pittenger and Stamen 1990). Similar results were seen in sugar maple (Acer saccharum) when the holes were filled with perlite backfill (Kalisz et al. 1994). However, roots of Monterey pine (Pinus radiata) were able to utilize $10 \mathrm{~mm}$ diameter vertical perforations to grow the same depth as uncompacted controls, while root growth of trees on compacted soil without perforations was suppressed (Nambiar and Sands 1992; Sheriff and Nambiar 1995). Largeleaf linden (Tilia platyphyllos) and planetree (Platanus $\times$ Acerifolia) roots colonized the majority of the depth of $10 \mathrm{~cm}$ diameter, $60 \mathrm{~cm}$ deep holes filled with a mix of coarse sand, composted organic materials, and fertilizer, and grew deeper than in adjacent site soils (Watson et al. 1996).

Root growth in larger trenches filled with compost-amended soil was increased relative to undisturbed soil, but root growth was not increased in the soils adjacent to the trenches after 2, 4, and 14 years. Soil aeration was not measured and may not have been limiting in the undisturbed and not compacted soil adjacent to the trenches (Watson et al. 1996; Watson 2002).

\section{pH Adjustment}

Neutral to slightly acid $\mathrm{pH}$ is optimum for most plants. Applications of lime are used to raise soil $\mathrm{pH}$. Aluminum sulfate and sulfur can help to lower $\mathrm{pH}$, although high rates of aluminum sulfate may cause injury to some plants, particularly in broadleaf evergreens. The injury is believed to be caused by excessive aluminum. Ammonium sulfate may be as effective as aluminum sulfate, but neither is as effective as granular sulfur (Messenger 1984). Ammonium sulfate is sometimes used if nitrogen application is needed along with $\mathrm{pH}$ reduction, but applying enough to lower the $\mathrm{pH}$ would likely apply a quick release form of nitrogen in excess of best management practices (Smiley et al. 2007).

Enhancing root development may improve uptake of available nutrients. Improving soil quality using methods such as cultivation, addition of organic amendments, and mulching can enhance root systems (see above). Basal drench application of paclobutrazol, a tree growth regulator, increased fine-root development and relieved interveinal chlorosis commonly attributed to iron deficiency of pin oak (Quercus palustris) on alkaline soils (Watson and Himelick 2004). 


\section{Salt Mitigation}

Soil salt accumulation can be reduced through design and engineering. Deicing salt accumulation in road median planters can be prevented by using wider planters with higher walls set farther from high-speed roads. The raised planters did not receive salt-laden runoff, splash, plowed snow, or direct application from salt spreaders (Rich and Walton 1979; Hootman et al. 1994).

Leaching of sodium from deicing salt application to roadways can be rapid in well-drained soils with adequate natural precipitation (Prior and Berthouex 1967; Cunningham et al. 2008). High soil salts and wet soils tended to occur together since poor drainage restricts the normal leaching of soil salts (Berrang et al. 1985). In arid regions, natural precipitation will not usually leach salt from the soil (Schuch et al 2008). Under low moisture conditions, moisture moves to the surface and evaporates and salt moves upward also to accumulate near the surface (Prior and Berthouex 1967). Flushing soil with water to remove salt and adding gypsum $\left(\mathrm{CaSO}_{4}\right)$ and fertilizers appear to be the best treatments for salt contaminated urban soils (Dobson 1991).

Selection of resistant species and cultivars can also minimize damage from salt in soils. The majority of published studies evaluate only shoot sensitivity, but growth of root systems of crapemyrtle (Lagerstroemia) cultivars varied in sensitivity to soil salt (Cabrera 2009).

\section{Biostimulants}

Application of commercial products to enhance root growth has been increasing. Soil application of mycorrhizal fungi have proven beneficial to trees in soils lacking the appropriate fungi, such as on strip-mining reclamation sites and in sterilized nursery beds (Smith and Read 1997). Native mycorrhizal fungi levels can be low in arid regions (Dag et al. 2009). However, growth rate of urban trees has generally been unaffected when treated with commercial inoculants at planting (Morrison et al. 1993; Martin and Stutz 1994; Roldan and Albaladejo 1994; Querejeta et al. 1998; Gilman 2001; Ferrini and Nicese 2002; Appleton et al.2003; Abbey and Rathier 2005; Corkidi et al. 2005; Broschat and Elliot 2009; Wiseman and Wells 2009).
Vigor of the natural mycorrhizal inoculum, as well as suitability of the introduced inoculum to the ecological conditions of the site, are important factors in the success or failure of the introduced inoculum (LeTacon et al. 1992). Endemic fungi species may replace the inoculated species over time (Garbaye and Churin 1996). Mycorrhizae can develop without introduced inoculation in a favorable soil environment if natural inoculum is present (Wiseman and Wells 2009).

The quality of the inoculum may be a factor in success of inoculations. Mycorrhizal colonization of roots rarely exceeded 5\% after treatment with commercial inoculants, but was up to $74 \%$ when treated with a fresh, lab-cultured inoculant (Wiseman et al. 2009; Fini et al. 2011).

Paclobutrazol (PBZ), a growth regulator used primarily to reduce shoot growth of trees, can also increase root growth under certain circumstances. Mycorrhizal colonization of root tips was unaffected by PBZ treatment, showing that mycorrhizae are not reduced by the fungicidal properties of PBZ (Watson 2006b).

Application of organic products, such as humates and plant extracts, have shown limited benefit to root growth of trees. Dose and species responses vary widely (Laiche 1991; Kelting et al. 1997; Kelting et al. 1998a; Kelting et al. 1998b; Ferrini and Nicese 2002; Fraser and Percival 2003; Gilman 2004; Sammons and Struve 2004; Abbey and Rathier 2005; Barnes and Percival 2006; Broschat and Elliot 2009; Percival 2013).

Compost teas are liquids containing soluble nutrients and species of bacteria, fungi, protozoa, and nematodes extracted from compost. Compost teas are being used to enhance soil biology and provide nutrients, sometimes as an alternative to fertilization, but research support for their effectiveness is lacking (Scharenbroch et al. 2011).

Sucrose can increase root:shoot ratios by downregulating genes used for photosynthesis (Percival and Fraser 2005). Applied as a root drench, it enhanced root vigor when applied at up to $70 \mathrm{~g} / \mathrm{L}$ in some studies (Percival 2004; Percival and Fraser 2005; Percival and Barnes 2007), but not others (Martinez-Trinidad et al. 2009). In most of these studies, the sugar was applied to the soil at least twice.

Healthy soils with favorable physical and chemical characteristics will support active soil 
biology naturally. Improving soil conditions is preferred over addition of compost teas, biostimulants, mycorrhizal fungi, and other means.

One of the most important soil functions is to serve as a medium for root growth. Physical, chemical, and biological soil characteristics all have an effect on tree roots. A thorough understanding of how these soil characteristics affect root growth is necessary to properly manage soils for optimum root growth. Although most urban soils are substantially altered from the natural state, or even completely manufactured, urban soils must still provide the necessary resources for root growth. Highly disturbed soils require very careful management to maintain conditions favorable for root growth. Management practices aimed at preventing soil damage or restoring aspects of the natural soil environment have the strongest research to support their effectiveness in improving root growth in urban and suburban settings.

Acknowledgements. We would like to thank the International Society of Arboriculture and the ISA Science and Research Committee for funding this literature review.

\section{LITERATURE CITED}

Abbey, T., and T. Rathier. 2005. Effects of mycorrhizal fungi, biostimulants, and water absorbing polymers on the growth and survival of four landscape plant species. Journal of Environmental Horticulture 23:108-111.

Abercrombie, R.A. 1990. Root distribution of avocado trees on a sandy loam soil as affected by soil compaction. Acta Horticulturae 275:505-512.

Abrisqueta, J.M., O. Mounzer, S. Alvarez, W. Conejero, Y. GarciaOrellana, L.M. Tapia, J. Vera, I. Abrisqueta, and M.C. RuizSanchez. 2008. Root dynamics of peach trees submitted to partial rootzone drying and continuous deficit irrigation. Agricultural Water Management 95:959-967.

Alberty, C.A., H.M. Pellett, and D.H. Taylor. 1984. Characterization of soil compaction at construction sites and woody plant response. Journal of Environmental Horticulture 2:48-53.

American Society of Agricultural Engineers. 1992. ASAE Standard: S313.2

Appleton, B., J. Koci, S. French, M. Lestyan, and R. Harris. 2003. Mycorrhizal fungal inoculation of established street trees. Journal of Arboriculture 29:107-110.

Armstrong, W., and D.J. Read. 1972. Some observations on oxygen transport in conifer seedlings. New Phytologist 71:55-62.

Armstrong, W., and M.C. Drew. 2002. Root growth and metabolism under oxygen deficiency. pp. 729-761. In: Waisel, Y., A. Eshel, and U. Kafkafi (Eds.). Plant Roots: The Hidden Half (third edition). Marcel Dekker, New York, New York, U.S.

Arnold, M.A., and G.V. McDonald. 2009. Groundcovers, organic and inorganic mulches, and masonry surfaces differentially affect establishment and root zone characteristics of urban trees. Arboriculture \& Urban Forestry 35:232-240.

Arnold, M.A., G.V. McDonald, and D.L. Bryan. 2005. Planting depth and mulch thickness affect establishment of green ash (Fraxinus pennsylvanica) and bougainvillea goldenraintree (Koelreuteria bipinnata). Journal of Arboriculture 31:163-170.

Ball, B.C., and M.F. O'Sullivan. 1982. Soil strength and crop emergence in direct drilled and ploughed cereal beds in seven field experiments. Journal of Soil Science 33:609-622.

Barnes, S., and G.C. Percival. 2006. Influence of biostimulants and water-retaining polymer root dips on survival and growth of newly transplanted bare-rooted silver birch and rowan. Journal of Environmental Horticulture 24:173-179.

Barnett, D. 1986. Root growth and water use by newly transplanted woody landscape plants. The Public Garden, April 23-25.

Baver, L.D., W.H. Gardner, and W.R. Gardner. 1972. Soil Physics (fourth edition). John Wiley \& Sons, Inc., New York City, New York, U.S. 498 pp.

Bechenbach, J., and J.H. Gourley. 1932. Some effects of different cultural methods upon root distribution of apple trees. Journal of the American Society of Horticultural Science 29:202-204.

Beeson, R.C., and K.G. Keller. 2001. Yard waste compost as a landscape soil amendment for azaleas. Journal of Environmental Horticulture 19:222-225.

Bell, D.T., and E.L. Johnson. 1974. Flood-caused tree mortality around Illinois reservoirs. Transactions of the Illinois State Academy of Science. 67:28-37.

Bengough, A.G., and C.E. Mullins. 1990. Mechanical impedance to root growth: A review of experimental techniques and root growth responses. Journal of Soil Science 41:341-358.

Bennie, A.T.P. 1991. Growth and mechanical impedance. pp. 393414. In: Y. Waisel, A. Eshel, and U. Kafkafi (Eds.). Plant Roots: The Hidden Half (third edition). Marcel Dekker, New York City, New York, U.S.

Benson, D.M. 1986. Relationship of soil temperature and moisture to development of Phytophthora root rot of azalea. Journal of Environmental Horticulture 4:112-115.

Benson, D.M., H.D. Shew, and R.K. Jones. 1982. Effects of raised and ground-level beds and pine bark on survival of azalea and population dynamics of Phytophthora cinnamomi. Canadian Journal of Plant Pathology 4:278-280.

Berrang, P., D.F. Karnosky, and B.J. Stanton. 1985. Environmental factors affecting tree health in New York City. Journal of Arboriculture 11:185-189.

Bevington, K.B., and W.S. Castle. 1985. Annual root growth pattern of young citrus trees in relation to shoot growth, soil temperature and soil water. Journal of American Society of Horticultural Science 110:840-845.

Bigras, F.J., and D. Dumais. 2005. Root-freezing damage in the containerized nursery: Impact on plantation sites: A review. New Forests 30:167-184.

Bigras, F.J., and H.A. Margolis. 1996. Shoot and root sensitivity of containerized black spruce, white spruce and jack pine seedlings to late fall freezing. New Forests 13:29-49.

Bilan, M.V. 1974. Relationship between needle moisture and root growth in loblolly pine seedlings. Ecology and Physiology of Root Growth. pp. 219-222. In: G. Hoffmann (Ed.). II International Symposium Ecology and Physiology of Root Growth. Akademie-Verlag, Berlin, Germany. 
Blackwell, P.S., and E.A. Wells. 1983. Limiting oxygen flux densities for oat root extension. Plant and Soil 73:129-139.

Blake, J., J. Zaerr, and S. Hee. 1979. Controlled moisture stress to improve cold hardiness and morphology of Douglas-fir seedlings. Forest Science 25:576-582.

Blaker, N.S., and J.D. MacDonald. 1981. Predisposing effects of soil moisture extremes on the susceptibility of rhododendron to Phytophthora root and crown rot. Phytopathology 71:831-834.

Blaker, N.S., and J.D. MacDonald. 1985. Effects of soil salinity on the formation of sporangia and zoospores of three isolates of Phytophthora. Phytopathology 75:270-274.

Blaker, N.S., and J.D. MacDonald. 1986. The role of salinity in the development of Phytophthora root rot of citrus. Phytopathology 76:970-975.

Bloom, A.J., F.S. Chapin III, and H.A. Mooney. 1985. Resource limitation in plants: An economic analogy. Annual Review of Ecology and Systematics 16:363-392.

Blouin, V. M., M.G. Schmidt, C.E. Bulmer, and M. Krzic. 2005. Mechanical disturbance impacts on soil properties and lodgepole pine growth in British Columbia's central interior. Canadian Journal of Soil Science 85:681-691.

Blouin, V.M., M.G. Schmidt, C.E. Bulmer, and M. Krzic. 2008 Effects of compaction and water content on lodgepole pine seedling growth. Forest Ecology and Management 255:2444-2452.

Blume, H-P. 1989. Characteristics of urban soils. pp. 23-46. In: German National committee (Ed.). UNESCO programme: Man and the Biosphere. International Scientific Workshop on Soils and Soil Zoology in Urban Ecosystems as a Basis for Management and Use of Green/Open Spaces.

Bockheim, J.G. 1974. Nature and properties of highly disturbed urban soils, Philadelphia, Pennsylvania. Paper presented before Div. S-5. Soil Science Society of America, Chicago, Illinois, U.S.

Bozkurt, M.A., T. Yardgac., and A. Yazzici. 2010. The use of sewage sludge as an organic matter source in apple trees. Polish Journal of Environmental Studies 19:267-274.

Brady, N.C., and R.R. Weil. 1996. The Nature and Properties of Soils. Prentice Hall, Upper Saddle River, New Jersey, U.S. 960 pp.

Brais, S., and C. Camire. 1998. Soil compaction induced by careful logging in the claybelt region of northwestern Quebec (Canada). Canadian Journal of Soil Science 78:197-206.

Braun, S., and W. Fluckiger. 1998. Soil amendments for plantings of urban trees. Soil \& Tillage Research 49:201-209.

Broschat, T.K., and M.L. Elliot. 2009. Effects of fertilization and microbial inoculants applied at transplanting on the growth of Mexican fan palm and queen palm. HortTechnology 19:324-330.

Bullock, P., and P.J. Gregory. 1991. Soils in the Urban Environment. Blackwell Scientific Publications, Oxford, Great Britain. 174 pp.

Bulmer, C.E., and D.G. Simpson. 2005. Soil compaction and water content as factors affecting the growth of lodgepole pine seedlings on sandy clay loam soil. Canadian Journal of Soil Science 85:667-679.

Callebaut, F., D. Gabriels, W. Minjauw, and M. De Boodt. 1982. Redox potential, oxygen diffusion rate, and soil gas composition in relation to water table level in two soils. Soil Science 134:149-156.

Carey, A.E., J.A. Gowan, T.J. Forenanol, H.Tai, and G.B. Wiersma. 1980. Heavy metal concentrations in soils of five United States cities, 1972 Urban Soils Monitoring Program. Pesticides Monitoring Journal 13:150-154.
Carlson, W.C. 1986. Root system considerations in the quality of loblolly pine seedlings. Southern Journal of Applied Forestry 10:87-92.

Carnell, R., and M.A. Anderson. 1986. A technique for extensive field measurement of soil anaerobism by using rusting of steel rods. Forestry 59:129-140.

Carter, C.E., and B. Rouge. 1986. Oxidation reduction due to a high water table. pp. 112-114. In: J. Saavalainen and P. Vakkilainen (Eds.). Proceedings, International Seminar on Land Drainage. Helsinki University of Technology, Helsinki, Finland.

Chalker-Scott, L. 2007. Impact of mulches on landscape plants and the environment: A review. Journal of Environmental Horticulture 25:239-249.

Chan, K.Y., L. Van Zwieten, I. Meszaros, A. Downie, and S. Joseph. 2007. Agronomic values of greenwaste biochar as a soil amendment. Australian Journal of Soil Research 45:629-634.

Chiapperini, G., and J.R. Donnelly. 1978. Growth of sugar maple seedlings in compacted soil. pp. 196-200. In: C.A. Hollis and A.E. Squillace (Eds.). Proceedings of the Fifth North American Forest Biology Workshop. School of Forest Resources and Conservation, University of Florida, Gainesville and The Southeastern Forest Experiment Station, USDA Forest Service.

Chinnow, D. 1975. Bodenveranderungen durch Carbonate und Streusalze im Westberliner Stadtgebiet. Mitteil Deutsche Bodenkundliche Gesellschaft 22:355-358.

Clapp, C.E., S.A. Stark, D.E. Clay, and W.E. Larson. 1986. Sewage sludge organic matter and soil properties. pp. 209-253. In: Y. Chen and Y. Avnimelech (Eds.). The Role of Organic Matter in Modern Agriculture. Martinus Nijhoff Publishers, Dordrecht, Netherlands.

Clark, L.J., W.R. Whalley, and P.B. Barraclough. 2003. How do roots penetrate strong soil? Plant and Soil 255:93-104.

Cogger, C., R., Hummel, J. Hart, and A. Bary. 2008. Soil and redosier dogwood response to incorporated and surface-applied compost. HortScience 43:2143-2150.

Cogger, C.G. 2005. Potential compost benefits for restoration of soils disturbed by urban development. Compost Science \& Utilization 13:243-251.

Corkidi, L., E.B. Allen, D. Merhaut, M.F. Allen, J. Downer, J. Bohn, and M. Evans. 2005. Effectiveness of commercial mycorrhizal inoculants on the growth of Liquidambar styraciflua in plant nursery conditions. Journal of Environmental Horticulture 23:72-76.

Corns, I.G.W., and D.G. Maynard. 1998. Effects of soil compaction and chipped aspen residue on aspen regeneration and soil nutrients. Canadian Journal of Soil Science 78:85-92.

Craul, P.J. 1985. A description of urban soils and their desired characteristics. Journal of Arboriculture 11:330-339.

Craul, P.J. 1992. Urban Soils in Landscape Design. John Wiley \& Sons Inc., New York, New York, U.S. 396 pp.

Craul, P.J., and C.F. Klein. 1980. Characterization of streetside soils in Syracuse, New York. METRIA 3:88-101.

Cunningham, M.A., E. Snyder, D. Yonkin, M. Ross, and E. Toren. 2008. Accumulation of deicing salts in soils in an urban environment. Urban Ecosystems 11:17-31.

Currie, J.A. 1984. Gas diffusion through soil crumbs: The effects of compaction and wetting. Journal of Soil Science 35:1-10.

Czerniawska-Kusza, I., G. Kusza, and M. Duzynski. 2004. Effect of deicing salts on urban soils and health status of roadside trees in the Opole region. Environmental Toxicolology 19:296-301. 
da Silva, A.P., and B.D. Kay. 1997. Estimating the least limiting water range of soils from properties and management. Soil Science Society of America Journal 61:877-883.

Daddow, R.L., and G.E. Warrington. 1983. Growth Limiting Soil Bulk Densities as Influenced by Soil Texture. US Forest Service, WSDG Report, WSDG-TN-00005. 17 p.

Dag, A., U. Yermiyahu, A. Ben-Gal, I. Zipori, and Y. Kapulnik. 2009. Nursery and post-transplant field response of olive trees to arbuscular mycorrhizal fungi in an arid region. Crop \& Pasture Science 60:427-433.

Davis, A.S., D.F. Jacobs, K.E. Wightman, and Z.K.D. Birge. 2006. Organic matter added to bareroot nursery beds influences soil properties and morphology of Fraxinus pennsylvanica and Quercus rubra seedlings. New Forests 31:293-303.

Day, S.D., and N.L. Bassuk. 1994. A review of the effects of soil compaction and amelioration treatments on landscape trees. Journal of Arboriculture 20:9-17.

Day, S.D., J.R. Seiler, and N. Persaud. 2000. A comparison of root growth dynamics of silver maple and flowering dogwood in compacted soil at differing soil water contents. Tree Physiology 20:257-263.

Day, S.D., N.L. Bassuk, and H. van Es. 1995. Effects of four compaction remediation methods for landscape trees on soil aeration, mechanical impedance, and tree establishment. Journal of Environmental Horticulture 13:64-71.

Day, S.D., P.E. Wiseman, S.B. Dickinson, and J.R. Harris. 2010a. Contemporary concepts of root system architecture or urban trees. Arboriculture \& Urban Forestry 36:149-159.

Day, S.D., P.E. Wiseman, S.B. Dickinson, and J.R. Harris. 2010 b. Tree root ecology in the urban environment and implications for a sustainable rhizosphere. Arboriculture \& Urban Forestry 36:193-205.

Dirr, M.A. 1975. Effects of salts and application methods on English ivy. HortScience 10:182-184.

Dobson, M.C. 1991. Deicing Salt Damage to Trees and Shrubs. Forestry Commission Bulletin 101. Forestry Commission, Farnham, Surrey, England.

Donnelly, J.R., and J.B. Shane. 1986. Forest ecosystem response to artificially induced soil compaction. I. Soil physical properties and tree diameter growth. Canadian Journal of Forest Research 16:750-754.

Drew, M.C. 1997. Oxygen deficiency and root metabolism: Injury and acclimation under hypoxia and anoxia. Annual Review of Plant Physiology and Plant Molecular Biology 48:223-250.

Duniway, J.M., and T.R. Gordon. 1986. Water relations and pathogen activity in soil. pp. 119-137. In: P. Ayres and L. Boddy (Eds.). Water, Fungi and Plants. Cambridge University Press, Cambridge, England.

Eavis, B.W. 1972. Soil physical conditions affecting seedling root growth. I. Mechanical impedance, aeration, and moisture availability as influenced by bulk density and moisture levels in a sandy loam soil. Plant and Soil 36:613-622.

Ehlers, W., U. Köpke, F. Hesse, and W. Böhm. 1983. Penetration resistance and root growth of oats in tilled and untilled loess soil. Soil and Tillage Research 3:261-275.

Eis, S. 1974. Root system morphology of western hemlock, western red cedar, and Douglas-fir. Canadian Journal of Forest Research $4: 28-38$.
Erhart, E., and W. Hart. 2003. Mulching with compost improves growth of blue spruce in Christmas tree plantations. European Journal of Soil Biology 39:149-156.

Erickson, A.E. 1982. Tillage effects on soil aeration. pp. 91-104. In: P.W. Unger and D.M. Van Doren Jr. (Eds.). Predicting Tillage Effects on Soil Physical Properties and Processes. American Society of Agronomy and the Soil Science Society of America, Madison, Wisconsin, U.S.

Ericssson, T., and T. Ingestad. 1988. Nutrition and growth of birch seedlings at varied relative phosphorus addition rates. Physiologia Plantarum 72:227-235.

Fales, S.L., and R.C. Wakefield. 1981. Effects of turfgrass on the establishment of woody plants. Agronomy Journal 81:605-610.

Feng, W., W. Duan, and H. Xu. 2008. Effects of different land use on physicochemical property and fertility of urban soil - A case study of Baoding city. Journal of Agricultural University of Hebei 31:61-64.

Ferrini, F., A. Fini, P. Frangi, and G. Amoroso. 2008. Mulching of ornamental trees: Effects on growth and physiology. Arboriculture \& Urban Forestry 34:157-162.

Ferrini, F., and F.P. Nicese. 2002. Response of English oak (Quercus robur L.) trees to biostimulants application in the urban environment. Journal of Arboriculture 28:70-75.

Fini, A., P. Frangi., G. Amoroso, R. Piatti, M. Faoro, C. Bellasio, and F. Ferrini. 2011. Effect of controlled inoculation with specific mycorrhizal fungi from the urban environment on growth and physiology of containerized shade tree species growing under different water regimes. Mycorrhiza 21:703-719.

Fite, K., E.T. Smiley, J. McIntyre, and C.E. Wells. 2011. Evaluation of a soil decompaction and amendment process for urban trees. Arboriculture \& Urban Forestry 37:293-300.

Fleming, R., N. Foster, J. Jeglum, and P. Hazlett. 1999. Soil compaction and sustainable productivity on coarse-textured jack pine sites. pp. 72-81. In: A.T. Lowe and C.T. Smith (Eds.). Developing Systems for Integrating Bioenergy into Environmentally Sustainable Forestry: Proceedings of the International Energy Agency Bioenergy Agreement Task 18. Forest Research Institute Bulletin 211. New Zealand Forest Research Institute, Rotorua, New Zealand.

Forristall, F.F., and S.P. Gessel. 1955. Soil properties related to forest cover type and productivity on the Lee Forest, Snohornish County, Washington. Soil Science Society of America Proceedings 19:384-389.

Foth, H.D. 1990. Fundamentals of Soil Science (eighth edition). John Wiley \& Sons Inc., New York, New York, U.S. 380 pp.

Fraedrich, S.W., and D.L. Ham. 1982. Wood chip mulching around maples: Effect on tree growth and soil characteristics. Journal of Arboriculture 8:85-89.

Fraser, G.A., and G.C. Percival. 2003. The influence of biostimulants on growth and vitality of three urban tree species following transplanting. Arboricultural Journal 27:43-57.

Froehlich, H.A., and D.S. McNabb. 1984. Minimizing soil compaction in Pacific Northwest forests. pp. 158-192. In: E.L. Stone (Ed.). Forest Soils and Treatment Impacts: Proceedings of the 6th North American Forest Soils Conference. University of Tennessee, Knoxville, Tennessee, U.S.

Froehlich, H.A., D.W.R. Miles, and R.W. Robbins. 1986. Growth of young Pinus ponderosa and Pinus contorta on compacted soil in central Washington. Forest Ecology Management 15:285-291. 
Gaertig, T., H. Schack-Kirchner, E.E. Hildebrand, and K. von Wilpert. 2002. The impact of soil aeration on oak decline in southwestern Germany. Forest Ecology and Management 159:15-25.

Garbaye, J., and J.L. Churin. 1996. Effect of ectomycorrhizal inoculation at planting on growth and foliage quality of Tilia tomentosa. Journal of Arboriculture 22:29-34.

Garcia-Orenes, F., C. Guerrero, J. Mataix-Solera, J. Navarro-Pedreno, I. Gomez, and I.J. Mataix-Beneyto. 2005. Factors controlling the aggregate stability and bulk density in two different degraded soils amended with biosolids. Soil \& Tillage Research 82:65-76.

Gerard, C.J., P. Sexton, and G. Shaw. 1982. Physical factors influencing soil strength and root growth. Agronomy Journal 74:875-879.

Gill, W.R., and R.D. Miller. 1956. A method for study of the influence of mechanical impedance and aeration on the growth of seedling roots. Proceedings of the Soil Science Society of America 20:154-157.

Gilman, E.F. 1989. Effects of injected and surface fertility on hibiscus growth in bare ground, mulch, and turf. Florida State Horticultural Society 102:144-145.

Gilman, E.F. 2001. Effect of nursery production method, irrigation, and inoculation with mycorrhizae-forming fungi on establishment of Quercus virginiana. Journal of Arboriculture 27:30-38.

Gilman, E.F. 2004. Effects of amendments, soil additives, and irrigation on tree survival and growth. Journal of Arboriculture 30:301-310.

Gilman, E.F., and J. Grabosky. 2004. Mulch and planting depth affect live oak (Quercus virginiana Mill.) establishment. Journal of Arboriculture 30:311-317.

Gilman, E.F., I.A. Leone, and F.B. Flower. 1982. Influence of soil gas contamination on tree root growth. Plant and Soil 65:3-10.

Gilman, E.F., I.A. Leone, and F.B. Flower. 1987. Effect of soil compaction and oxygen content on vertical and horizontal root distribution. Journal of Environmental Horticulture 5:33-36.

Gomez, A., R.F. Powers, M.J. Singer, and W.R. Horwath. 2002. Soil compaction effects on growth of young ponderosa pine following litter removal in California's Sierra Nevada. Soil Science Society of America Journal 66:1334-1343.

Graves W. R., and L.C. Wilkins. 1991. Growth of honey locust seedlings during high root-zone temperature and osmotic stress. HortScience 26:1312-1315.

Graves, W.R. 1991. Growth and iron content of three legume tree species at high root-zone temperature. Journal of Arboriculture 17:313-317.

Graves, W.R. 1994. Urban soil temperatures and their potential impact on tree growth. Journal of Arboriculture 20:24-27.

Graves, W.R. 1998. Consequences of high soil temperatures. pp. 2735. In: D. Neely and G.W. Watson (Eds.). The Landscape Below Ground II. International Society of Arboriculture, Champaign, Illinois, U.S.

Graves, W.R., and A.S. Aiello. 1997. High root-zone temperature causes similar changes in water relations and growth of silver maples from $33^{\circ}$ and $44^{\circ} \mathrm{N}$ latitude. Journal of American Society of Horticultural Science 122:195-199.

Graves, W.R., and M.N. Dana. 1987. Root-zone temperature monitored at urban sites. HortScience 22:613-614.

Graves, W.R., M.N. Dana, and R.J. Joly. 1989a. Root-zone temperature affects water status and growth of red maple. Journal of American Society of Horticultural Science 114:406-410.
Graves, W.R., M.N. Dana, and R.J. Joly. 1989b. Influence of rootzone temperature on growth of Ailanthus altissima (Mill.) Swingle. Journal of Environmental Horticulture 7:79-82.

Graves, W.R., R.J. Joly, and M.N. Dana 1991. Water Use and Growth of Honey Locust and Tree-of-Heaven at High Root-zone Temperature. HortScience 26:1309-1312.

Gray, L.E., and R.A. Pope. 1986. Influence of soil compaction on soybean stand, yield, and Phytophthora root rot incidence. Agronomy Journal 78:189-191.

Greacen, E.L., and R. Sands. 1980. Compaction of forest soils: A review. Australian Journal of Soil Resesearch 18:163-189.

Green, T.L., and G.W. Watson. 1989. Effects of turfgrass and mulch on the establishment and growth of bare-root sugar maples. Journal of Arboriculture 15:268-272.

Greenly, K.M., and D.A. Rakow. 1995. The effect of wood mulch type and depth on weed and tree growth and certain soil parameters. Journal of Arboriculture 21:225-232.

Grossman, R.B., and T.G. Reinsch. 2002. Bulk density and linear extensibility. pp. 201-228. In: J.H. Dane and G. Clarke Topp (Eds.). Methods of Soil Analysis. Part 4. Physical Methods. ASA and SSSA, Madison, Wisconsin, U.S.

Gur, A., B. Bravdo, and Y. Mizrahi. 1972. Physiological responses of apple trees to supraoptimal root temperatures. Physiologia Plantarum 27:130-138.

Guttay, A.J.R. 1976. Impact of deicing salts upon the endomycorrhizae of roadside sugar maples. Soil Society of America Journal 40:952-954.

Halverson, H.G., and G.M. Heisler. 1981. Soil temperatures under urban trees and asphalt. USDA Forest Service Research Paper NE-481.

Halverson, H.G., and R.P. Zisa. 1982. Measuring the response of conifer seedlings to soil compaction stress. USDA Forest Service Research Paper NE-509. 6 pp.

Handel, S.N., G.R. Robinson, W.F. J. Parsons, and J.H. Mattei. 1997. Restoration of woody plants to capped landfills: Root dynamics in an engineered soil. Restoration Ecology 5:178-186.

Hansen E.M., P.B. Hamm, A.J. Julius, and L.F. Roth. 1979. Isolation, incidence, and management of Phytophthora in forest tree nurseries in the Pacific Northwest. Plant Disease Reporter 63:607-611.

Hanslin, H. M., A. Saebo, and O. Bergersen. 2005. Estimation of oxygen concentration in the soil gas phase beneath compost mulch by means of a simple method. Urban Forestry \& Urban Greening 4:37-40.

Harris, J.R., N.L. Bassuk, R.W. Zobel, and T.H. Whitlow. 1995. Root and shoot growth periodicity of green ash, scarlet oak, Turkish hazelnut, and tree lilac. Journal of American Society of Horticultural Science 120:211-216.

Harris, R.W., J.L. Paul, and A.T. Leiser. 1977. Fertilizing Woody Plants. University of California, Division of Agricultural Sciences Leaflet 2958. 23 pp.

Hatchell, G.E., C.W. Ralston, and R.R Foil. 1970. Soil disturbances in logging. Journal of Forestry 68:772-775.

Havis, J.R. 1976. Root hardiness of woody ornamentals. HortScience 11:385-386.

Headly, D.B., and N. Bassuk. 1991. Effect of time of application of sodium chloride in the dormant season on selected tree seedlings. Journal of Environmental Horticulture 9:130-136.

Heilman, P. 1981. Root penetration of Douglas-fir seedlings into compacted soil. Forest Science 27:660-666. 
Heinicke, A.J. 1932. The effect of submerging the roots of apple trees at different seasons of the year. Proceeds of the American Society for Horticulture Science 29:205-207.

Hensley, D.L., R.E. McNeil, and R. Sundheim. 1988. Management influences growth of transplanted Magnolia grandiflora. Journal of Arboriculture 14:204-207.

Herrick, G.T. 1988. Relationships between soil salinity, sap-sugar concentration, and health of declining roadside sugar maples (Acer saccharum). Ohio Journal of Science 88:192-194.

Himelick, E.B., and G.W. Watson. 1990. Reduction of oak chlorosis with wood chip mulch treatments. Journal of Arboriculture $16: 275-278$.

Hironori, O., and M. Hisayuki. 2006. Alkalinization of concreteneighboring area and urban greening. Environmental Information Science 35:84-85.

Hodge, S.J. 1991. Improving the Growth of Established Amenity Trees: Site Physical Conditions. Arboriculture Research Note 102. Department of the Environment, UK. 4 pp.

Hodge, S.J., and K. Knott. 1993. Practical guide to the use of steel rods for the assessment of aeration in urban soils. Journal of Arboriculture 19:289-294.

Hodge, S.J., and R. Boswell. 1993. A study of the relationship between site conditions and urban tree growth. Journal of Arboriculture 19:358-367.

Hodge, S.J., R. Boswell, and K. Knott. 1993. Development of the steel rod technique for the assessment of aeration in urban soils. Journal of Arboriculture 19:281-288.

Hofstra, G., R. Hall, and G.P. Lumis. 1979. Studies of salt-induced damage to roadside plants in Ontario. Journal of Arboriculture 5:25-31.

Holmes, F.W. 1961. Salt injury to trees. Phytopathology 51:712-718.

Hook, D.D., C.L. Brown, and P.P. Kormanik. 1971. Inductive flood tolerance in swamp tupelo (Nyssa sylvatica var. biflora). Journal of Experimental Botany 22:78-89.

Hootman, R.G., P.D. Kelsey, R. Reid, and K. von der Heide-Spravka. 1994. Factors affecting accumulation of deicing salts in soils around trees. Journal of Arboriculture 20:196-201.

Hopkins, R.M., and W.H. Patrick Jr. 1969. Combined effect of oxygen content and soil compaction on root penetration. Soil Science 108:408-413.

Howard, R.F., M.J. Singer, and G.A. Frantz. 1981. Effects of soil properties, water content, and compactive effort on the compaction of selected California forest and range soils. Soil Science Society of America Journal 45:231-236.

Hullugalle, N.R., and R. Lal. 1986. Root growth of maize in a compacted gravelly tropical alfisol as affected by rotation with a woody perennial. Field Crops Research 13:33-44.

Hummel, R.L., and C.R. Johnson. 1985. Amended backfills: Their cost and effect on transplant growth and survival. Journal of Environmental Horticulture 3:76-79.

Hutchinson, F.E., and B.E. Olson. 1967. Relationship of road salt applications to sodium and chloride ion levels in the soil bordering major highways. Highway Resource Record 193:1-7.

Huttermann, A., M. Zommorodi, and K. Reise. 1999. Addition of hydrogels to soil for prolonging the survival of Pinus halepensis seedlings subjected to drought. Soil \& Tillage Research 50:295-304.

Iles, J.K., and M.S. Dosmann. 1999. Effect of organic and mineral mulches on soil properties and growth of Fairview Flame red maple trees. Journal of Arboriculture 25:163-167.
Ingestad, T., and A-B. Lund. 1979. Nitrogen stress in birch seedlings I. Growth technique and growth. Physiologia Plantarum 45:137-148.

Jacobs, D.F., and V.R. Timmer. 2005. Fertilizer-induced changes in rhizosphere electrical conductivity: Relation to forest tree seedling root system growth and function. New Forests 30:147-166.

Jacobs, D.F., R. Rose, D.L. Haase, and P.O. Alzugaray. 2004. Fertilization at planting impairs root system development and drought avoidance of Douglas-fir (Pseudotsuga menziesii) seedlings. Annals of Forest Science 61:643-651.

Jacobs, K.A. 2005.The potential of mulch to transmit three tree pathogens. Journal of Arboriculture 31:235-242.

Janz, D., and A. Polle. 2012. Harnessing salt for woody biomass production. Tree Physiology 32:1-3.

Jim, C.Y. 1993a. Soil compaction as a constraint to tree growth in tropical \& subtropical urban habitats. Environmental Conservation 20:5-49.

Jim, C.Y. 1993b. Massive tree-planting failure due to multiple soil problems. Arboricultural Journal 17:309-331.

Jim, C.Y. 1998a. Physical and chemical properties of a Hong Kong roadside soil in relation to urban tree growth. Urban Ecosystems 2:171-181.

Jim, C.Y. 1998b. Urban soil characteristics and limitations for landscape planting in Hong Kong. Landscape and Urban Planning 40:235-249.

Johansson, K., G. Orlander, and U. Nilsson. 2006. Effects of mulching and insecticides on establishment and growth of Norway spruce. Canadian Journal of Forest Research 36:2377-2385.

Jones, C.A. 1983. Effect of soil texture on critical bulk densities for root growth. Soil Science Society of America Journal 47:1208-1211.

Juzwik J., R.R. Allmaras, and K.M. Gust. 1997. Soil tillage practices and root disease management. pp. 23-28. In: T.D. Landis and J.R. Thompson (Tech. Coords.). National Proceedings, Forest and Conservation Nursery Assoc. USDA Forest Service Pacific Northwest Research Station General Technical Report PNW-GTR-419.

Jordan, D., F. Ponder, Jr., and V.C. Hubbard. 2003. Effects of soil compaction, forest leaf litter and nitrogen fertilizer on two oak species and microbial activity. Applied Soil Ecology 23:33-41.

Kalisz, P.J., J.W. Stringer, and R.J. Wells. 1994. Vertical mulching of trees: Effects on roots and water status. Journal of Arboriculture 20:141-145.

Kätterer, T., A. Fabião, M. Madeira, C. Ribeiro, and E. Steen. 1995. Fine-root dynamics, soil moisture and soil carbon content in a Eucalyptus globulus plantation under different irrigation and fertilization regimes. Forest Ecology and Management 74:1-12.

Kaufmann, M.R. 1968. Water relations of pine seedlings in relation to root and shoot growth. Plant Physiology 43:281-288.

Keever, G.J., G.S. Cobb, J.C. Stephenson, and W.J. Foster. 1989. Effect of hydrophylic polymer amendment on growth of container grown landscape plants. Journal of Environmental Horticulture 7:52-56.

Kelting, M., J.R. Harris, J. Fanelli, and B. Appleton. 1998a. Biostimulants and soil amendments affect two-year posttransplant growth of red maple and Washington hawthorn. HortScience 33:819-822.

Kelting, M., J.R. Harris, J. Fanelli, and B. Appleton. 1998b. Humatebased biostimulants affect early post-transplant root growth and sapflow of balled-and-burlapped red maple. HortScience 33:342-344. 
Kelting, M., J.R. Harris, J. Fanelli, B. Appleton, and A. Niemiera. 1997. Humate-based biostimulants do not consistently increase growth of container-grown Turkish hazelnut. Journal of Environmental Horticulture 15:197-199.

Kochian, L.V. 1995. Cellular mechanisms of aluminum toxicity and resistance in plants. Annual Review in Plant Physiology and Plant Molecular Biology 46:237-260.

Kopinga, J., and J. van den Burg. 1995. Using soil and foliar analysis to diagnose the nutritional status of urban trees. Journal of Arboriculture 21:17-24.

Korotaev, A.A. 1992. Bodenverdichtung und Wurzelwachstum der Bäume. Forstarchiv 63:116-119.

Kozlowski, T.T. 1985. Soil aeration, flooding, and tree growth. Journal of Arboriculture 11:85-96.

Kramer, P.J., and T.T. Kozlowski. 1979. Physiology of Woody Plants. Academic Press, New York City, New York, U.S. 811 pp.

Krapfenbauer, A., G. Glatzel, and Z.H. Wu. 1974. Damage to trees by deicing salts. Can scientific research help to save trees in our cities? Die Bodenkultur 25:54-62.

Kraus, H.T. 1998. Effects of mulch on soil moisture and growth of desert willow. HortTechnology 8:588-590.

Lagerwerf, J.V., and A.W. Specht. 1970. Contamination of roadside soil and vegetation with cadmium, nickel, lead, and zinc. Environmental Science and Technology 4:583-586.

Laiche, A.J. Jr. 1991. Evaluation of Humic Acids and Slow-release Fertilizers on Container-grown Landscape Plants. Research Report - Mississippi Agricultural \& Forestry Experiment Station 16:1-3.

Laird, D.A., P. Fleming, D.D. Davis, R. Horton, B. Wang, and D.L. Karlen. 2010. Impact of biochar amendments on the quality of a typical Midwestern agricultural soil. Geoderma 158:443-449.

Landon, J.R. (Ed.). 1991. Booker Tropical Soil Manual. Longman, Burnt Mill, Harlow, UK. 474 p.

Langille, A.R. 1976. One season's salt accumulation in soil and trees adjacent to a highway. Hortscience 11:575-576.

Larson, M.M. 1970. Root regeneration and early growth of red oak seedlings: Influence of soil temperature. Forest Science 16:442-446.

Lemaire, F., G. David, J.P. Rossignol, and L. Beaudet. 1999. Loosening of urban soils with a lance-injector. Acta Horticulturae 496:421-428

LeTacon, F., I.F. Alvarez, D. Bouchard, B. Henrion, R.M. Jackson, S. Luff, J.I. Parlade, J. Pera, E. Stenstrom, N. Villeneuve, and C. Walker. 1992. Variations in field response of forest trees to nursery ectomycorrhizal inoculation in Europe. pp. 119-134. In: D.J. Read, D.H. Lewis, A.H. Fitter, and I.J. Alexander (Eds.). Mycorrhizas in ecosystems. CAB International, Cambridge, United Kingdom.

Letey, J. 1985. Relationship between soil physical properties and crop condition. pp. 277-294. In: B.A. Stewart (Ed.). Advances in Soil Science. Springer-Verlag, New York City, New York, U.S.

Liang, J., J. Zhang, G.Y.S. Chan, and M.H. Wong. 1999. Can differences in root responses to soil drying and compaction explain differences in performance of trees growing on landfill sites? Tree Physiology 19:619-624.

Lichter, J.M., and P.A. Lindsey. 1994. The use of surface treatments for the prevention of soil compaction during site construction. Journal of Arboriculture 20:205-209.

Lincoln, M.C., R.E. Will, L.A. Morris, E.A. Carter, D. Markewitz, J.R. Britt, B. Cazell, and V. Ford. 2007. Soil change and loblolly pine (Pinus taeda) seedling growth following site preparation tillage in the Upper Coastal Plain of the southeastern United States. Forest Ecology and Management 242:558-568.

Linde, M., H. Bengtsson, and I. Oborn. 2001. Concentrations and pools of heavy metals in urban soils in Stockholm, Sweden. Water, Air, and Soil Pollution: Focus 1:83-101.

Lindstrom, A. 1986. Freezing temperature in the root zone - Effects on growth of containerized Pinus sylvestris and Picea abies seedlings. Scandinavian Journal of Forest Research 1:371-378.

Litzow, M., and H. Pellett. 1983. Influence of mulch materials on growth of green ash. Journal of Arboriculture 9:7-11.

Lloyd, J., and J.A. Taylor. 1994. On the temperature dependence of soil respiration. Functional Ecology 8:315-323.

Lowery, B. and J.E. Morrison. 2002. Soil penetrometers and penetrability. pp. 363-388. In: J.H. Dane and G. Clark Topp (Eds.). Methods of soil analysis. Part 4, Physical Methods. ASA and SSSA, Madison, Wisconsin, U.S.

Lunt, O.R., J. Letey, and S.B. Clark. 1973. Oxygen requirements for root growth in three species of desert shrubs. Ecology 54:1356-1362.

Lyr, H., and G. Hoffmann. 1967. Growth rates and growth periodicity of tree roots. pp. 181-236. In: J.A. Romberger and P. Mikola (Eds.). International Review of Forestry Research, Volume 2. Academic Press, New York City, New York, U.S.

MacDonald, J.D., L.R. Costello, and T. Berger. 1993. An evaluation of soil aeration status around healthy and declining oaks in an urban environment in California. Journal of Arboriculture 19:209-219.

Madji, H., and H. Persson. 1989. Effects of road-traffic pollutants (lead and cadmium) on tree fine roots along a motor road. Plant and Soil 119:1-5.

Marschner, H., and V. Römbeld. 1996. Root-induced changes in the availability of micronutrients in the rhizosphere. pp. 557-580. In: Y. Waisel, A. Eshel, and U. Kafkafi (Eds.). Plant Roots: The Hidden Half. Marcel Dekker, Inc., New York City, New York, U.S.

Martin, C.A., and D.L. Ingram. 1991. Root growth of southern magnolia following exposure to high root-zone temperatures. HortScience 26:370-371.

Martin, C.A., and J.C. Stutz. 1994. Growth of Argentine mesquite inoculated with vesicular-arbuscular mycorrhizal fungi. Journal of Arboriculture 20:134-139.

Martinez-Trinidad, T., W.T. Watson, M.A. Arnold, and L. Lombardini. 2009. Investigations of exogenous applications of carbohydrates on the growth and vitality of live oaks. Urban Forestry \& Urban Greening 8:41-48.

McMillin, J.D., and M.R. Wagner. 1995. Effects of water stress on biomass partitioning of ponderosa pine seedlings during primary root growth and shoot growth periods. Forest Science 41:594-610.

Meier, I.C., and C. Leuschner. 2008. Belowground drought response of European beech: Fine root biomass and carbon partitioning in 14 mature stands across a precipitation gradient. Global Change Biology 14:2081-2095.

Meskimen, G. 1970. Combating grass competition for Eucalyptus planted in turf. Tree Planter Notes 21:3-5.

Messenger, S. 1986. Alkaline runoff, soil pH, and white oak manganese deficiency. Tree Physiology 2:317-325.

Messenger, S.M. 1984. Treatment of chlorotic oaks and red maples by soil acidification. Journal of Arboriculture 10:122-128. 
Minore, D., C.E. Smith, and R.F. Woollard. 1969. Effects of high soil density on seedling root growth of seven north-western tree species. USDA Forest Service Research Note PNW-112. 6 pp.

Misra, R.K., and A.K. Gibbons. 1996. Growth and morphology of eucalypt seedling-roots in relation to soil strength arising from compaction. Plant and Soil 182:1-11.

Miyamoto, S. 2012. Salinization of Irrigated Urban Soils: A Case Study of El Paso, TX. Texas Water Resources Institute, TR-433.

Moffat, A.J., and R.C. Boswell. 1997. The effectiveness of cultivation using the winged tine on restored sand and gravel workings. Soil Tillage Research 40:111-124.

Montague, T., C. McKenny, M. Maurer, and B. Winn. 2007. Influence of irrigation volume and mulch on establishment of select shrub species. Arboriculture \& Urban Forestry 33:202-209.

Montague, T., R. Kjelgren, and L. Rupp. 1998. Surface energy balance affects gas exchange of three shrub species. Journal of Arboriculture 24:254-262.

Morrison, S.J., P.A. Nicholl, and P.R. Hicklenton. 1993. VA mycorrhizal inoculation of landscape trees and shrubs growing under high fertility conditions. Journal of Environmental Horticulture 11:64-71.

Mount, H., L. Hernandez, T. Goddard, and S. Indrick. 1999. Temperature signatures for anthropogenic soils in New York City. pp 137-140. In: J.M. Kimble, R.J. Ahrens, and R.B. Bryant (Eds.). Classification, Correlation, and Management of Anthropogenic Soils Proceedings. Nevada and California Workshop. USDANRCS, National Soils Survey Center, Lincoln, Nebaska, U.S.

Mukhtar, S., J.L. Baker, and R.S. Kanwar. 1996. Effect of short-term flooding and drainage on soil oxygenation. Transactions of the American Society of Agricultural Engineers 39:915-920.

Myers, M.K., and H.C. Harrison. 1988. Evaluation of container plantings in an urban environment. Journal of Arboriculture 14:293-297.

Nambiar, E.K., G.D. Bowen, and R. Sands. 1979. Root regeneration and plant water status of Pinus radiata D. Don seedlings transplanted to different soil temperatures. Journal of Experimental Botany 30:1119-1131.

Nambiar, E.K.S., and R. Sands. 1992. Effects of compaction and simulated root channels in the subsoil on root development, water uptake, and growth of radiata pine. Tree Physiology 10:297-306.

Newman, E.I. 1966. Relationship between root growth of flax (Linum usitatissimum) and soil water potential. New Phytologist 65:273-283.

Nielsen, J.S., and H.N. Rasmussen. 1999. Mycorrhizal status and morphotype diversity in Tilia cordata - A pilot study of nurseries and urban habitats. Acta Horticulturae 496:451-459.

Nieuwenhuis, M., J. Wills, J. Gardiner, E. Sundstrom, and M. Keane 2003. The effect of soil cultivation methods on rooting depth of young Sitka spruce [Picea sitchensis (Bong.) Carr.] trees on wet mineral soils in Ireland. Forestry 76:465-477.

NRCS Soil Quality Institute. 2000. Urban Soil Compaction. United States Department of Agriculture Natural Resources Conservation Service Soil Quality - Urban Technical Note No. 2.

Olesinski, J., M.B. Lavigne, and M.J. Krasowski. 2011. Effects of soil moisture manipulations on fine root dynamics in a mature balsam fir (Abies balsamea L. Mill.) forest. Tree Physiology 31:339-348.

Ownley, B.H., and D.M. Benson. 1991. Relationship of matric water potential and airfilled porosity of container media to develop- ment of Phytophthora root rot of rhododendron. Phytopathology 81:936-94.

Page-Dumroese, D.S., M.F. Jurgensen, A.E. Tiarks, F. Ponder, F.G. Sanchez, R.L. Fleming, J.M. Kranabetter, R.F. Powers, D.M. Stone, J.D. Elioff, and D. Scott. 2006. Soil physical property changes at the North American long-term soil productivity study sites: 1 and 5 years after compaction. Canadian Journal of Forest Research 36:551-564.

Pan, E., and N.L. Bassuk. 1985. Effects of soil type and compaction on the growth of Ailanthus altissima seedlings. Journal of Environmental Horticulture 3:158-162.

Patterson, J.C, J.J. Murray, and J.R. Short. 1980. The impact of urban soils on vegetation. METRIA 3:33-56.

Patterson, J.C. 1976. Soil compaction and its effects upon urban vegetation. pp. 91-101. In: F.S. Santamour, H.D. Gerhold, and S. Little (Eds.). Better Trees for Metropolitan Landscapes. USDA Forest Service General Technical Report NE-22. Upper Darby, PA.

Patterson, J.C. 1977. Soil compaction: Effects on urban vegetation. Journal of Arboriculture 3:161-167.

Pearson, R.W. 1965. Soil environment and root development. pp. 110-115. In: W.H. Pierre, D. Kirkham, J. Pesek, and R. Shaw (Eds.). Plant Environment and Efficient Water Use. American Society of Agronomy, Madison, Wisconsin, U.S.

Pellett, H. 1981. Soil temperature effects on urban plants. New Horizons. Horticultural Research Institute. Washington, D.C., U.S. pp. 34-36.

Percival, C.G. 2004. Sugar feeding enhances root vigor of young trees following containerization. Journal of Arboriculture 30:357-364.

Percival, G.C. 2013. Failure of biostimulants to enhance drought and salt tolerance in urban trees. Arboriculture \& Urban Forestry (in press).

Percival, G.C., and G.A. Fraser. 2005. Use of sugars to improve root growth and increase transplant success of birch (Betula pendula Roth.). Journal of Arboriculture 31:66-77.

Percival, G.C., and S. Barnes. 2007. The influence of carbohydrates, nitrogen fertilizers, and water-retaining polymer root dips on survival and growth of newly transplanted bare rooted silver birch (Betula pendula Roth.) and European beech (Fagus sylvatica L.). Arboricultural Journal 30:223-244.

Pezeshki, S.R. 1991. Root responses of flood-tolerant and floodsensitive tree species to soil redox conditions. Trees 5:180-186.

Pittenger, D.R., and T. Stamen 1990. Effectiveness of methods used to reduce harmful effects of compacted soil around landscape trees. Journal of Arboriculture 16:55-57.

Polanco, M.C., J.J. Zwiazek, and M.C. Voicu. 2008. Responses of ectomycorrhizal American elm (Ulmus americana) seedlings to salinity and soil compaction. Plant and Soil 308:189-200.

Prasad, M.N.V. (Ed.). 2004. Heavy Metal Stress in Plants from Biomolecules to Ecosystems (second edition). Springer-Verlag, Berlin Heidelberg, Germany. 462 pp.

Prior, G., and P.M. Berthouex. 1967. A study of salt pollution of soil by highway salting. Highway Resource Record 193:8-21.

Proebsting, E.L. 1943. Root distribution of some deciduous fruit trees in a California orchard. Proceedings of the American Society of Horticulture Science 43:1-4.

Qian, Y.L., and B. Mechamb. 2005. Long-Term Effects of Recycled Wastewater Irrigation on Soil Chemical Properties on Golf Course Fairways. Agronomy Journal 97:717-721. 
Querejeta, J. I., A. Roldan, J. Albaladejo, and V. Castillo. 1998. The role of mycorrhizae, site preparation, and organic amendment in the afforestation of a semi-arid Mediterranean site with Pinus halepensis. Forest Science 44:203-211.

Randrup, T.B. 1997. Soil compaction on construction sites. Journal of Arboriculture 23:207-210.

Randrup, T.B., and K. Dralle. 1997. Influence of planning and design on soil compaction in construction sites. Landscape and Urban Planning 38:87-92.

Reisinger, T.W., G.L. Simmons, and P.E. Pope. 1988. The impact of timber harvesting on soil properties and seedling growth in the South. Southern Journal of Applied Forestry. 12:58-67.

Rich, S., and G.S. Walton. 1979. Decline of curbside sugar maples in Connecticut. Journal of Arboriculture 5:265-268.

Richardson, S.D. 1953. Root growth of Acer pseudoplatanus L. in relation to grass cover and nitrogen deficiency. Mededelingen Landbouwhogesch Wageningen 53:75-97.

Richardson-Calfee, L.E., J.R. Harris, and J.K. Fanelli. 2007. Posttransplant root and shoot growth periodicity of sugar maple. Journal of American Society of Horticultural Science 132:147-157.

Rickman. K.W., J. Letey, and L.H. Stolzy. 1966. Plant response to oxygen supply and physical resistance in the root environment. Soil Science Society of America Proceedings 30:304-307.

Roldan, A., and J. Albaladejo. 1994. Effect of mycorrhizal inoculation and soil restoration on the growth of Pinus halepensis seedlings in a semiarid soil. Biology and Fertility of Soils 18:143-149.

Rolf, K. 1991. Soil improvement and increased growth response from subsoil cultivation. Journal of Arboriculture 17:200-204.

Rolf, K. 1993. Methods for Recultivation of Compacted Soil in Urban Areas. Sveriges Lantbruksuniversitet Institutionen for Lantbruksteknik Rapport 0:1-55.

Ross, E.A., and L.A. Hardy. 1997. National Engineering Handbook, part 652, Irrigation Guide. National Resource Conservation Service, National Cartography and Geospatial Center, Fort Worth, Texas, U.S.

Ruiz-Canales, A., J.A. Franco, V. Plana, and J.M. Abrisqueta. 2006. Root distribution in apricot orchard (Prunus armeniaca L. 'Bulida') under trickle irrigation. Acta Horticulturae 717:307-311.

Russell, R.S. 1977. Plant Root Systems: Their Function and Interaction with the Soil. McGraw-Hill, London, England, UK. 298 pp.

Sammons, J.D., and D.K. Struve. 2004. Effect of Bioplex ${ }^{\mathrm{mm}}$ on transplant success of non-dormant red oak (Quercus rubra L.). Journal of Environmental Horticulture 22:197-201.

Sands, R., E.L. Greacen, and C.J. Gerard. 1979. Compaction of sandy soils in radiata pine forests: I. A penetrometer study. Australian Journal of Soil Research 17:101-113.

Santamour, F.S., Jr. 1979. Root hardiness of green ash seedlings from different provenances. Journal of Arboriculture 5:276-279.

Schaan, C.M., D.A. Devitt, R.L. Morris, and L. Clark. 2003. Cyclic irrigation of turfgrass using a shallow saline aquifer. Agronomy Journal 95:660-667.

Scharenbroch, B.C. 2009. A meta-analysis of studies published in Arboriculture \& Urban Forestry relating to organic materials and impacts on soil, tree, and environmental properties. Arboriculture \& Urban Forestry 35:221-231.

Scharenbroch, B.C., W. Treasurer, M. Catania, and V. Brand. 2011. Laboratory assays on the effects of aerated compost tea and fertilization on biochemical properties and denitrification in $\mathrm{A}$ silt loam and Bt clay loam soils. Arboriculture \& Urban Forestry $37: 269-277$.

Scheyer, J.M., and K.W. Hipple. 2005. Urban Soil Primer. United States Department of Agriculture, Natural Resources Conservation Service, National Soil Survey Center, Lincoln, Nebraska, U.S. Accessed 05/21/2013. <http://soils.usda.gov/use>

Schuch, U.K., J.Walworth, T. Mahato, and A. Pond. 2008. Accumulation of Soil Salinity in Landscapes Irrigated with Reclaimed Water. pp. 68-73. In: University of Arizona Turfgrass, Landscape and Urban IPM Research Summary (P-155).

Sena Gomes, A.R., and T.T. Kozlowski. 1980. Responses of Pinus halepensis seedlings to flooding. Canadian Journal of Forest Research 10:308-311.

Sheriff, D.W., and E.K.S. Nambiar. 1995. Effect of subsoil compaction and three densities of simulated root channels in the subsoil on growth, carbon gain, and water uptake of Pinus radiata. Australian Journal of Plant Physiology 22:1001-1013.

Shirazi, A.M., and S.H. Vogel. 2007. Temperature fluctuation in Fraxinus pennsylvanica var. subintegerrima and its surrounding environment. Arboriculture \& Urban Forestry 33:193-201.

Short, J.R., D.S. Fanning, M.S. Mclntosh, J.E. Foss, and J.C. Patterson. 1986. Soils of the Mall in Washington, D.C. I. Statistical summary of properties. Soil Science Society of America Journal 50:699-705.

Siegel-Issem, C.M., J.A. Burger, R.F. Powers, F. Ponder, and S.C. Patterson. 2005. Seedling root growth as a function of soil density and water content. Soil Science Society of America Journal 69:215-226.

Simini, M., and I.A. Leone. 1986. Studies on the effects of deicing salts on roadside trees. Arboricultural Journal 10:221-231.

Simmons, G.L., and P.E. Pope. 1985. Effects of soil compaction on root growth characteristics of yellow-poplar and sweetgum seedlings. pp. 264-268. In: J.O. Dawson and K.A. Majerus (Eds.). Proceedings of the Fifth Central Hardwood Forestry Conference. Dept. of Forestry. University of Illinois, UrbanaChampaign, Illinois, U.S.

Singer, C.K., and C.A. Martin. 2008. Effect of landscape mulches on desert landscape microclimates. Arboriculture \& Urban Forestry 34:230-237.

Singer, C.K., and C.A. Martin. 2009. Effect of landscape mulches and drip irrigation on transplant establishment and growth of three North American desert native plants. Journal of Environmental Horticulture 27:166-170.

Sinnett, D., J. Poole, and T.R. Hutchings. 2008. A comparison of cultivation techniques for successful tree establishment on compacted soil. Forestry 81:663-679.

Smiley, E.T, S.J. Lilly, and P. Kelsey. 2007. Best Management Practices: Tree and shrub fertilization. International Society of Arboriculture, Champaign, Illinois, U.S. 34 pp.

Smiley, E.T., G.W. Watson, B.R. Fraedrich, and D.C. Booth. 1990. Evaluation of soil aeration equipment. Journal of Arboriculture 16:118-123.

Smith, K.D., P.B. May, and G.M. Moore. 2001. The influence of compaction and soil strength on the establishment of four Australian landscape trees. Journal of Arboriculture 27:1-7.

Smith, S.E., and D.J. Read. 1997. Mycorrhizal Symbiosis (second edition). Academic Press, New York City, New York, U.S. 605 pp.

Soil and Water Conservation Society (SWCS). 2000. Soil Biology Primer (revised edition). Ankeny, Iowa: Soil and Water Conser- 
vation Society. Accessed 05/21/2013. <http://soils.usda.gov/sqi/ concepts/soil_biology/biology.html>

Solfjeld, I., and P.A. Pedersen. 2006. Growth of Betula pendula Roth. The first season after transplanting at two phenological stages. Urban Forestry \& Urban Greening 5:101-106.

Stabler, L.B., C.A. Martin, and J.C. Stutz. 2001. Effect of urban expansion on arbuscular mycorrhizal fungal mediation of landscape tree growth. Journal of Arboriculture 27:193-202.

State of California. 1978. Wastewater Reclamation Criteria. California Administrative Code. Title 22, Division 4, California Department of Health Services, Sanitary Engineering Section, Berkeley, California.

Stepniewski, W., S.R. Pezeshki, R.D. DeLaune, and W.H. Patrick, Jr. 1991. Root studies under variable redox potential in soil or soil suspensions using laboratory rhizotrons. Vegetatio 94:47-55.

Stewart, V.I., and J. Scullion. 1989. Principles of managing manmade soils. Soil Use and Management 5:109-116.

Stolzy, L.H. 1974. Soil atmosphere. pp. 335-362. In: E.W. Carson (Ed.). The Plant Root and Its Environment. University Press of Virginia, Charlottesville, Virginia, U.S.

Stolzy, L.H., and J. Letey. 1964. Correlation of plant response to soil oxygen diffusion rates. Hilgardia 35:567-576.

Stolzy, L.H., and R.E. Sojka. 1984. Effects of flooding in plant disease. pp. 261-264. In: T.T. Kozlowski (Ed.). Flooding and Plant Growth. Academic Press, New York City, New York, U.S.

Stolzy, L.H., J. Letey, L.J. Klotz, and C.K. Labanauskas. 1965. Water and aeration as factors in root decay of Citrus sinensis. Phytopathology 55:270-275.

Stone, D.M., and J.D. Elioff. 1998. Soil properties and aspen development five years after compaction and forest floor removal. Canadian Journal of Soil Science 78:51-58.

Stone, D.M., and R. Kabzems. 2002. Aspen development on similar soils in Minnesota and British Columbia after compaction and forest floor removal. Forestry Chronicle 78:886-891.

Struve, D.K., and B.C. Moser. 1985. Soil temperature effects on root regeneration of scarlet oak seedings. Research Circular - Ohio Agricultural Research and Development Center 2841:12-14.

Studer, E.J., P.L. Steponkus, G.L. Good, and S.L. Wiest. 1978. Root hardiness of container-grown ornamentals. HortScience 13:172-174.

Sutherland, J.R. 1984. Pest management in northwest bareroot nurseries. pp. 203-210. In: M.L. Duryea and T.D. Landis (Eds.). Forest Nursery Manual: Production of Bareroot Seedlings. Martinus Niijhoff/Dr. W. Junk Publishers, The Hague, Netherlands.

Tackett, J.L., and R.W. Pearson. 1964. Oxygen requirements of cotton seedling roots for penetration of compacted soil cores. Proceedings of the Soil Science Society of America 28:600-605.

Taylor, H.M., and E. Burnett. 1964. Influence of soil strength on the root-growth habits of plants. Soil Science 98:174-180.

Taylor, H.M., and G.S. Brar. 1991. Effects of soil compaction on root development. Soil \& Tillage Research 19:111-119.

Taylor, H.M., G.M. Robertson, and J.J. Parker. 1966. Soil strengthroot penetration relations for medium to coarse-textured soil materials. Soil Science 102:18-22.

Timonen, S., and P. Kauppinen. 2008. Mycorrhizal colonization patterns of Tilia trees in street, nursery, and forest habitats in southern Finland. Urban Forestry \& Urban Greening 7:265-276.

Todhunter, M.N., and W.F. Beineke. 1979. Effect of fescue on black walnut growth. Tree Planter's Notes 30:20-23.
Torreano, S.J, and L.A Morris. 1998. Loblolly pine root growth and distribution under water stress. Soil Science Society of America Journal 62:818-827.

Tripepi, R.R., M.W. George, R.K. Dumroese, and D.L. Wenny. 1991. Birch seedling response to irrigation frequency and a hydrophilic polymer amendment in a container medium. Journal of Environmental Horticulture 9:119-123.

Truax, B., and G. Gagnon. 1993. Effects of straw and black plastic mulching on the initial growth and nutrition of butternut, white ash, and bur oak. Forest Ecology and Management 57:17-27.

Tworoski, T.J., J.A. Burger, and D.W. Smith. 1983. Soil texture and bulk density affect early growth of white oak seedlings. Tree Planter's Notes. 34:22-25.

Unger, P.W., and T.C. Kaspar. 1994. Soil compaction and root growth: A review. Agronomy Journal 86:759-766

Valoras, N., J. Letey, L.H. Stolzy, and E.F. Frolich. 1964. The oxygen requirements for root growth of three avocado varieties. Proceedings of the American Society of Horticulture Science $85: 172-178$.

van Noordwijk, M., H.M. Widianto, and K. Hairiah. 1991. Old tree root channels in acid soils in the humid tropics: Important for crop production, water infiltration, and nitrogen management. Plant and Soil 134:7-44.

van Schoor, L., P.J.C. Stassen, and A. Botha. 2008. Effect of biological soil amendments on tree growth and microbial activity in pome fruit orchards. Acta Horticulturae 767:309-318.

Vartapetian, B.B., and M.B. Jackson. 1997. Plant adaptations to anaerobic stress. Annals of Botany 79:3-20.

Vaz, C.M.P., J.M. Manieri, I.C. de Maria, and M. Tuller. 2011. Modeling and correction of soil penetration resistance for varying soil water content. Geoderma 166:92-101.

von Wilpert, K., and J. Schaffer. 2006. Ecological effects of soil compaction and initial recovery dynamics: A preliminary study. European Journal of Forest Research 125:129-138.

Waddington, D.V., and J.H. Baker. 1965. Influence of soil aeration on the growth and chemical composition of three grass species. Agronomy Journal 57:253-256.

Walmsley, T.J., B. Hunt, and A.D. Bradshaw. 1991. Root growth, water stress and tree establishment. pp. 38-43. In: S.J. Hodge (Ed.). Research for Practical Arboriculture. Forestry Commission Bulletin 97, HMSO, London, UK.

Walters, D.T., and A.R. Gilmore. 1976. Allelopathic effects of fescue on growth of sweetgum. Journal of Chemical Ecology 2:469-479.

Wang, J., J.D. Hesketh, and J.T. Wooley. 1986. Preexisting channels and soybean rooting patterns. Soil Science 141:432-437.

Wang, M., and M. Zhang. 2004. The comparison of soil properties in different function zones of urban and suburban districts in Hangzhou city. Acta Agriculturae Zhejiangensis 16:377-380.

Watson, G.W. 1988. Organic mulch and grass competition influence tree root development. Journal of Arboriculture 14:200-203.

Watson, G.W. 2002. Soil replacement: Long-term results. Journal of Arboriculture 28:229-230.

Watson, G.W. 2006a. Establishing a relationship between soil aeration and fine root development of seven tree species using the steel rod technique. Arboricultural Journal 29:161-171.

Watson, G.W. 2006b. The effect of paclobutrazol treatment on starch content, mycorrhizal colonization, and fine root density of white oaks (Quercus alba L.). Arboriculture \& Urban Forestry $32: 114-117$ 
Watson, G.W., and E.B. Himelick. 2004. Effects of soil pH, root density, and tree growth regulator treatments on pin oak chlorosis. Journal of Arboriculture 30:172-177.

Watson, G.W., and G. Kupkowski. 1991. Effects of a deep layer of mulch on the soil environment and tree root growth. Journal of Arboriculture 17:243-245.

Watson, G.W., and P. Kelsey. 2006. The impact of soil compaction on soil aeration and fine root density of Quercus palustris. Urban Forestry \& Urban Greening 4:69-74.

Watson, G.W., P. Kelsey, and K. Woodtli. 1996. Replacing soil in the root zone of mature trees for better growth. Journal of Arboriculture 22:167-172.

Weaver, M. J., and R.J. Stipes. 1988. White pine decline: A case study from Virginia landscapes. Journal of Arboriculture 14:109-120.

Webster, D.H. 1978. Soil conditions associated with absence or sparse development of apple roots. Canadian Journal of Plant Science 58:961-969.

Weltecke, K., and T. Gaertig 2012. Influence of soil aeration on rooting and growth of the Beuys-trees in Kassel, Germany. Urban Forestry \& Urban Greening 11:329-338.

Wester, H.V., and E.E. Cohen. 1968. Salt damage to vegetation in the Washington, D.C. area during the 1966-67 winter. Plant Disease Reporter 52:350-354.

White, R.M. 1973. Plant tolerance for standing water: An assessment. Cornell Plantations 28:50-52.

Whitlow, T.H., and R.W. Harris. 1979. Flood Tolerance in Plants: A State-of-the-Art Review. Vicksburg, Mississippi, U.S. Army Engineer Waterways Experiment. Station Tech. Rpt. E-79-2. 161 pp.

Williamson, J. R., and W.A. Neilsen. 2003. The effect of soil compaction, profile disturbance, and fertilizer application on the growth of eucalypt seedlings in two glasshouse studies. Soil \& Tillage Research 71:95-107.

Winkelmann, M., and A.D. Kendle. 1996. The effect of hydrophilic polyacrylamide gels on establishment of woody plants under droughted and saline conditions. Arboricultural Journal 20:387-404.

Wiseman P.E., and C.E. Wells. 2005. Soil inoculum potential and arbuscular mycorrhizal colonization of Acer rubrum in forested and developed landscapes. Journal of Arboriculture 31:296-302.

Wiseman P.E., and C.E. Wells. 2009. Arbuscular mycorrhizal inoculation affects root development of Acer and Magnolia species. Journal of Environmental Horticulture 27:70-79.

Wiseman, P.E, K.H. Colvin, and C.E. Wells. 2009. Performance of mycorrhizal products marketed for woody landscape plants. Journal of Environmental Horticulture 27:41-50.

Wong, T.L., R.W. Harris, and R.E. Fissell. 1971. Influence of high soil temperatures on five woody-plant species. Journal of American Society of Horticultural Science 96:80-82.

World Meteorological Organization. 2008. WMO guide to meteorological instruments and methods of observation WMO-No. 8 (seventh edition). Accessed 05/21/2013. <www.wmo.int/pages/ prog/www/IMOP/CIMO-Guide.html>
Worrall, J. 2004. Armillaria root disease. The Plant Health Instructor. Accessed 05/21/2013. DOI:10.1094/PHI-I-2004-0706-01. $<$ www.apsnet.org/edcenter/intropp/lessons/fungi/Basidiomycetes/Pages/Armillaria.aspx $>$

Wright, A.N., S.L. Warren, and F.A. Blazich. 2007. Effect of rootzone temperature on survival, growth, and root morphology of Kalmia latifolia and Ilex crenata 'Compacta'. Journal of Environmental Horticulture 25:73-77.

Wright, R.A., R.W. Wein, and B.P. Dancik. 1992. Population differentiation in seedling root size between adjacent stands of jack pine. Forest Science 38:777-785.

Yang, J., F. Zhang, Y. Zhao, W. Ruan, and Y. He. 2005. Application and comparison of soil compaction indexes in the evaluation of urban soils. Transactions of the Chinese Society of Agricultural Engineering 21:51-55.

Yelenosky, G. 1963. Soil aeration and tree growth. Proceedings of the International Shade Tree Conference 39:16-25.

Yelenosky, G. 1964. Tolerance of trees to deficiencies of soil aeration. Proceedings of the International Shade Tree Conference 40:27-147.

Youngberg, C.T. 1959. The influence of soil conditions following tractor logging on growth of planted Douglas-fir. Proceedings of the Soil Science Society of America 23:76-78.

Zisa, R.P., H.G. Halverson, and B.B. Stout. 1980. Establishment and early growth of conifers on compact soils in urban areas. Forest Service Research Paper NE-451. 8 pp.

Gary W. Watson (corresponding author)

The Morton Arboretum

4100 Illinois Route 53

Lisle, Illinois 60532, U.S.

gwatson@mortonarb.org

Angela M. Hewitt

The Morton Arboretum

4100 Illinois Route 53

Lisle, Illinois 60532, U.S.

Melissa Custic

The Morton Arboretum

4100 Illinois Route 53

Lisle, Illinois 60532, U.S.

Marvin Lo

The Morton Arboretum

4100 Illinois Route 53

Lisle, Illinois 60532, U.S. 
Zusammenfassung. Die physischen, chemischen und biologischen Zusammensetzungen von städtischen Böden enthalten oft Begrenzungen für das Wachstum von Wurzeln. Für ein gutes Management ist ein Verständnis für die Beziehungen der Bodenanteil sehr wichtig. Als ein Resultat dieser gegenseitigen Abhängigkeiten kann der Status eines Bodenfaktors alle anderen beeinflussen. Die Vermeidung von Bodenschäden ist sehr effektiv und erstrebenswert. Pflegemaßnahmen, wie Kultivierung und Mulchen können effektiv die Bodeneigenschaften verbessern. Zusätze für den Boden, wie Produkte zur Biostimulation, haben sich in der Forschung als nicht zuverlässig effektiv erwiesen. Die Herausforderung an das Management ist, eine urbane Umwelt zu liefern, die nahezu wie eine natürliche Umgebung funktioniert.

Resumen. Las restricciones físicas, químicas y biológicas de los suelos urbanos suelen plantear limitaciones para el crecimiento de las raíces de los árboles. La comprensión de las interrelaciones de las propiedades del suelo es importante para un adecuado manejo. Como resultado de la interdependencia de las propiedades del suelo, el estado de uno de los factores del suelo puede tener un efecto sobre todos los demás. La prevención de daños en el suelo es preferida; las prácticas culturales tales como el cultivo y el acolchado son apropiadas en la mejora de las propiedades del suelo. Los aditivos del suelo, tales como productos bioestimulantes, no han demostrado ser consistentemente eficaces a través de la investigación. El desafío del manejo es proporcionar un entorno urbano que funcione como el medio ambiente natural 